NBER WORKING PAPER SERIES

\title{
ESCAPING IMPORT COMPETITION IN CHINA
}

\author{
Ana Cecília Fieler \\ Ann Harrison \\ Working Paper 24527 \\ http://www.nber.org/papers/w24527 \\ NATIONAL BUREAU OF ECONOMIC RESEARCH \\ 1050 Massachusetts Avenue \\ Cambridge, MA 02138 \\ April 2018, Revised January 2020
}

Previously circulated as "Escaping Import Competition and Downstream Tariffs." We are especially grateful to Jonathan Eaton for his readings of previous drafts. We thank Matilde Bombardini, Teresa Fort, Elisa Giannone, Beata Javorcik, and Esteban Rossi-Hansberg for their suggestions. The research for this paper was conducted in part while Fieler was visiting the Economics Department at Princeton University. We thank them for their hospitality. The views expressed herein are those of the authors and do not necessarily reflect the views of the National Bureau of Economic Research.

NBER working papers are circulated for discussion and comment purposes. They have not been peer-reviewed or been subject to the review by the NBER Board of Directors that accompanies official NBER publications.

(C) 2018 by Ana Cecília Fieler and Ann Harrison. All rights reserved. Short sections of text, not to exceed two paragraphs, may be quoted without explicit permission provided that full credit, including (c) notice, is given to the source. 
Escaping Import Competition in China

Ana Cecília Fieler and Ann Harrison

NBER Working Paper No. 24527

April 2018, Revised January 2020

JEL No. F12,F13,F14

\begin{abstract}
$\underline{\text { ABSTRACT }}$
In a stylized model, firms differentiate their products to escape import com- petition. Facing a nested CES demand, each firm chooses between a nest with competitors and its own nest under higher costs. The profit from differentiation is an inverted U-shaped function of firm productivity. It increases with import competition and is lower than the social benefit. Differentiation increases the gains from trade. In establishment data from China spanning its 2001 WTO accession, tariff cuts are associated with increases in productivity, introduction of new goods, switches to skillintensive sectors. Markups in the model explain the large increases in revenue productivity among small firms and input suppliers.
\end{abstract}

\author{
Ana Cecília Fieler \\ Yale University \\ Department of Economics \\ 27 Hillhouse Ave \\ New Haven, CT 06511 \\ and NBER \\ ana.fieler@yale.edu \\ Ann Harrison \\ Haas School of Business \\ University of California, Berkeley \\ 2220 Piedmont Ave \\ Berkeley, CA 94720 \\ and NBER \\ harrison@haas.berkeley.edu
}

A online appendix is available at http://www.nber.org/data-appendix/w24527 


\section{Introduction}

Policy makers and trade economists generally agree that trade reforms improve the performance of domestic competitors in developing countries. While this view is mostly supported by empirical work, it is at odds with standard theories of international trade. ${ }^{1}$ Based on increasing returns to scale, theories such as Melitz (2003) and its extensions with endogenous innovation predict that tightening competition decreases within-firm productivity by decreasing the scale of production and the rents from innovation. ${ }^{2}$ We propose a short extension of Atkeson and Burstein (2008), a commonly used model in trade, in which domestic firms respond to reductions in trade costs by innovating to escape foreign competition. We then provide supportive evidence for the model using a panel of Chinese firms spanning the years of China's accession to the WTO in 2001.

In practice, domestic firms escape foreign competition by catering to domestic tastes, offering greater customization, and bundling products with non-tradable services. For example, the cell phone company Xiaomi prevented the expansion of Apple in China by offering Chinese language options and a superior integration of its software with local apps. Chery Automobiles introduced several new, small car models with many optional features, and it made replacement parts readily available. Not only do small and fuelefficient cars appeal to Chinese consumers, but it is difficult for firms producing cars abroad to offer customized accoutrements and a wide range of replacement parts because they have long lead times. ${ }^{3}$

We model this type of strategy as a shift toward an unexploited market niche insulated from foreign competition. Demand is nested constant elasticity of substitution (CES). There's a continuum of sectors, each with a finite number of heterogeneous firms. In decreasing order of productivity in a sector, each firm chooses whether (1) to exit, (2) to produce a variety in a nest with other competitors, or (3) to incur a higher (fixed or variable) cost and produce in a new nest where it is a monopolist. All firms then simultaneously set prices. The choice of product differentiation, between (2) and (3), is our only departure from Atkeson and Burstein (2008).

\footnotetext{
${ }^{1}$ Tybout (2003) surveys studies of trade liberalizations in developing countries in the 1980s and 1990s, and Shu and Steinwender (2019) surveys more recent studies. Recent papers, such as Amiti and Konings (2007), Fernandes (2007), Gorodnichenko et al. (2010), Eslava et al. (2013), DeLoecker et al. (2016) find either positive or insignificant results. As we see below, revenue productivity is not a good proxy for innovation in the model because pro-competitive effects on markups decrease measured productivity.

${ }^{2}$ These extensions focus on export expansion and imported inputs, which increase firm size. They include Lileeva and Trefler (2010), Aw et al. (2011), Bustos (2011) and Bøler et al. (2015). In Caliendo and Rossi-Hansberg (2012), improvements in efficiency occur through the reorganization of the firm.

${ }^{3}$ See Farhoomand and Schuetz (2007), Boyd et al. (2008), Teagarden and Fifi (2015), Feng and Wei (2015) for case studies from China.
} 
Section 2 studies a closed economy. The incremental profit from differentiation is a non-monotonic function of the firm's productivity. If the firm is very unproductive, its profit is small in any nest. If the firm is much more productive than its competitors, it will hold near monopoly power and charge a high markup even in the common nest. The benefit from further differentiation is then small. This simpler, closed-economy setting is also useful to derive results later applied to understand international trade.

Section 3 introduces international trade and input suppliers to the model to suit our empirical context. Foreign firms can only sell varieties in the common nest, an assumption in line with the interpretation of differentiation as a shift toward a less-tradable market niche. A reduction in trade costs in a sector increases exit and differentiation among import-competing firms. Markups increase for firms that differentiate and decrease for other firms. If two firms, originally in the common nest, make the same discrete choice after the shock, the markup of the smaller firm increases relative to the larger firm. Intuitively, the small firm's price is closer to cost. So, it has a limited scope to decrease markups in response to tighter competition in the common nest, but it increases its markup by more than the large firm if they both differentiate.

Less-differentiated inputs are only used to produce less-differentiated downstream output. The trade shock downstream increases exit, differentiation and markups among input suppliers. This markup increase contrasts with the ambiguous change in the markups of import-competing firms. ${ }^{4}$

We prove that a firm's profit from differentiation is always smaller than the social welfare gain. If differentiation doesn't require large fixed costs, it increases with large reductions in trade costs widespread across sectors. Then, the welfare gains from trade in the model are larger than in a standard model without the differentiation option.

Section 4 provides reduced-form evidence using a panel of Chinese firms from 1998 to 2007. During the period, China joined the WTO, average tariffs on manufacturing fell from 18 to 9.4 percent, and imports as a share of GDP doubled from 14 to 28 percent.

In the data, tariff cuts are associated with firms' introduction of new goods and with switches to more skill-intensive sectors. ${ }^{5}$ These patterns are broadly consistent with the model, since the predicted product differentiation changes a firm's output and may in practice shift it to more skill-intensive tasks. For example to increase its offerings of car

\footnotetext{
${ }^{4}$ The markup result, in Section 3, arises because markups in Atkeson and Burstein (2008) depend on relative costs, not on total sales. This feature also holds in Bernard et al. (2003) and Melitz and Ottaviano (2008). See Arkolakis et al. (2017) for a general model of trade and variable markups.

${ }^{5}$ To mitigate the problem of endogeneity, we follow the literature in using initial tariffs as instruments for tariff changes. See Goldberg et al. (2009), Amiti and Konings (2007), Attanasio et al. (2004). We cannot observe changes in skill intensity because we only observe skill intensity in one year.
} 
parts and models, Chery Automobiles invested in research and development, and in skillintensive technologies such as modern machinery amenable to production in small batches and integrated computer systems that enable just-in-time inventory controls. While shifts to skill-intensive tasks often occur within sectors, some may imply a switch in the firm's four-digit sectoral classification. Common sector switches in the data include from cotton and chemical fibers to textile and garment manufacturing, and from steel rolling processing to metal structures. They suggest upgrading to higher value-added sectors with a greater scope for differentiation.

Tariff cuts in the data are also associated with increases in revenue productivity within import-competing firms and their input suppliers. The effect is larger for small firms (significant in some specifications) and it is five to ten times larger for input suppliers. ${ }^{6}$ Although puzzling at a first sight, these asymmetries conform to the predictions of the model on markups. And since revenue productivity is an estimate of the ratio of revenue to cost, it maps better to markups in the model than to firms' decision to differentiate. ${ }^{7}$

Section 5 tests the robustness of the empirical results, and Section 6 concludes.

Holmes and Stevens (2014) also observe that firms with customized products are more insulated from foreign competition. We extend their model to account for endogenous product differentiation and markups (their focus is firm size). Consistent with our findings, Brandt and Thun (2010, 2016) describe the increased market segmentation in China during the period of our analysis. ${ }^{8}$ The welfare question on optimal variety appears in Spence (1976a,b), Dixit and Stiglitz (1977) and Dhingra and Morrow (2018), although our approach differs from the later two papers, which study monopolistic competition settings.

In Aghion et al. (2005, 2015) and Akcigit et al. (2018), import competition also spurs innovation by decreasing the profit from inaction, and the gains from innovation are non-monotonic in firm productivity. But in these models, competition comes from lessproductive firms, and accordingly, they are used to study firms in rich countries facing competition from poor countries. These models also feature homogeneous goods within sectors and only the most productive firm produces. We bring their results closer to quantitative models with co-existing differentiated varieties. Other mechanisms, such as technology diffusion, agency problems within firms and offshoring, may also be at work in the data, but they generally cannot account for all the empirical regularities above. ${ }^{9}$

\footnotetext{
${ }^{6}$ Brandt et al. (2017) and Chen and Steinwender (2019) find similar results on firm size.

${ }^{7}$ See Section 4.4 for further discussion and references. Methods to decompose productivity into TFPQ and markups are inconsistent with our model.

${ }^{8}$ The notion that firms escape competition by seeking market niches where they are monopolists is common in the business literature (Porter (2008)) and in interviews with entrepreneurs (Rose (2015)).

${ }^{9}$ See Sampson (2015), Perla et al. (2015), Buera and Oberfield (2016) for technology diffusion and
} 
Brandt et al. (2017) previously document the relation between tariff cuts and withinfirm productivity in China. We complement their results with other firm outcomes and indirect input linkages. Goldberg et al. (2010) also link trade shocks to the introduction of new goods, and Goldberg and Pavcnik (2004, 2007) survey studies on import competition and demand for skills in developing countries. ${ }^{10}$ The indirect effect of a shock on input suppliers appears in the context of foreign direct investment (Javorcik (2004)), imported inputs (Eslava et al. (2015)), export expansion (Linarello (2018)), and regional disparities (Acemoglu et al. (2016)).

\section{A Closed Economy}

We set up the model here. Sections 2.1 and 2.2 present the positive and welfare results, respectively. Households inelastically supply labor, the unique input into production, to a perfect labor market. We normalize the total labor endowment to one and take wages to be the numeraire. There is a continuum of sectors $S \in[0,1]$, each containing a finite and exogenous set of heterogeneous firms. Each firm produces a single variety. Firms' discrete choices partition the set of non-exiting varieties into nests, and consumers have standard nested CES preferences.

Firms Each firm $i$ chooses among three discrete choices: (i) to exit, (ii) to produce a less-differentiated variety, or (iii) to produce a differentiated variety. If the firm exits, it gets zero profits. All less-differentiated varieties in sector $S$ are in the same nest, denoted with $\mathcal{L}_{S}$. Each differentiated variety $i$ has its own nest $\{i\}$. If firm $i$ is less-differentiated, it pays a fixed cost $f_{L}$ and a per-unit $\operatorname{cost} c_{i L}$ to produce. If it is differentiated, its fixed cost is $f_{D}$ and its unit cost is $c_{i D}$.

Demand We write $i \in n$ whenever firm $i$ is in nest $n$ and $n \in S$ whenever nest $n$ is in sector $S$. The demand for a variety with price $p$ in nest $n$ is

$$
q(p, n)=\bar{P}^{\eta-1} P_{n}^{\sigma-\eta} p^{-\sigma} y
$$

trade, and Holmes and Schmitz (2010) and Chen and Steinwender (2019) for agency models. Offshoring does not explain why our results all hold in a subsample with only non-exporting firms. Firms respond to competition by switching specialization in Nocke (2006) and Lim et al. (2019), but like the models above, competition must come from below in order to increase firm markups.

${ }^{10}$ For recent work on trade and labor, see Topalova (2010), Autor et al. (2013), Dix-Carneiro and Kovak (2017). Only a small fraction of firms in China engage in R\&D and patenting, common proxies for innovation in developed countries. 
where

$$
\begin{aligned}
& P_{n}=\left[\sum_{i \in n} p_{i}^{1-\sigma}\right]^{\frac{1}{1-\sigma}}, \\
& \bar{P}=\left[\int_{0}^{1} \sum_{n^{\prime} \in S} P_{n^{\prime}}^{1-\eta} d S\right]^{\frac{1}{1-\eta}},
\end{aligned}
$$

$y$ is total spending and $p_{i}$ is the price of variety $i$. The elasticity of substitution between nests is $\eta$ irrespective of whether nests are in the same sector or not for simplicity. The elasticity of substitution between varieties within a nest is $\sigma$. Assume $\sigma>\eta>1$. For a differentiated firm $i$, demand reduces to $q(p,\{i\})=\bar{P}^{\eta-1} p^{-\eta} y$.

Game within a Sector In ascending order of $\operatorname{costs} c_{i L}$, each firm in sector $S$ decides among the three discrete choices above (i) exit, (ii) less-differentiation, and (iii) differentiation. Once all discrete choices are made, firms simultaneously set prices. Production and trade take place, and payoffs are realized. ${ }^{11}$

We consider the subgame perfect equilibrium (SPE) and solve it by backward induction. After all discrete choices are made, each firm chooses the price that best responds to other firm's prices. From (1), firm $i$ in nest $n$ with unit cost $c$ solves

$$
\begin{array}{cl}
\max _{p} & \bar{P}^{\eta-1} P_{n}^{\sigma-\eta} p^{-\sigma} y(p-c) \\
\text { subject to } & P_{n}=\left(p^{1-\sigma}+\sum_{i^{\prime} \in n, i^{\prime} \neq i} p_{i^{\prime}}^{1-\sigma}\right)^{1 /(1-\sigma)} .
\end{array}
$$

Taking the first order conditions, the markup over marginal cost is $\epsilon /(\epsilon-1)$ where

$$
\begin{aligned}
& \epsilon=\sigma(1-s)+\eta s \\
& s=\left(\frac{p}{P_{n}}\right)^{1-\sigma} .
\end{aligned}
$$

The elasticity of demand $\epsilon$ is a weighted average between the elasticity within nest $\sigma$ and the elasticity across nests $\eta$, where the weight $s$ is the firm's market share in revenue.

\footnotetext{
${ }^{11}$ The timing of firms' discrete choices according to productivity is a standard equilibrium selection mechanism, also in Atkeson and Burstein (2008), Edmond et al. (2015).
} 
If firm $i$ is differentiated, $s=1, \epsilon=\eta$, and its operating profit (4) is

$$
\pi_{D}\left(c_{i D}\right)=\frac{\bar{P}^{\eta-1}}{\eta}\left(\frac{\eta c_{i D}}{\eta-1}\right)^{1-\eta} y
$$

For less-differentiated firms, equation (5) implicitly defines prices in a nest as a function of unit costs. Define $P_{L}(\mathbf{c})$ as the price index (2) when the vector of unit costs is $\mathbf{c}$, and $\epsilon_{L}(c, \mathbf{c})$ as the elasticity of demand (5) of a firm with unit cost $c$ when the vector of its competitors' costs is c. The operating profit (4) of firm $i \in \mathcal{L}_{S}$, facing competitors in $\mathcal{L}_{S}$ with unit costs $\mathbf{c}_{-i L}$, is

$$
\pi_{L}\left(c_{i L}, \mathbf{c}_{-i L}\right)=\bar{P}^{\eta-1} \frac{P_{L}\left(\left\{c_{i L}, \mathbf{c}_{-i L}\right\}\right)^{\sigma-\eta}}{\epsilon_{L}\left(c_{i L}, \mathbf{c}_{-i L}\right)}\left(\frac{c_{i L} \epsilon_{L}\left(c_{i L}, \mathbf{c}_{-i L}\right)}{\epsilon_{L}\left(c_{i L}, \mathbf{c}_{-i L}\right)-1}\right)^{1-\sigma} y
$$

Name the $m_{S}$ firms in sector $S$ so that $c_{1 L} \leq \ldots \leq c_{m_{S} L}$. Denote an action of firm $i$ with $g_{i} \in \mathcal{G}=$ \{exit, less differentiation, differentiation\}. A vector of actions $\left(g_{1}, \ldots, g_{m_{S}}\right)$ determines the sets of exiting, less-differentiated, and differentiated firms. By backward induction, starting with the least productive firm, for $i=m_{S}, \ldots, 1$ and all possible actions $\left(\tilde{g}_{1}, \ldots, \tilde{g}_{i-1}\right)$, firm $i$ chooses among three subgames with starting nodes $\left(\tilde{g}_{1}, \ldots, \tilde{g}_{i-1}, g_{i}\right)$ for $g_{i} \in \mathcal{G}$. Since it anticipates the actions of firms $i+1, \ldots, m_{S}$ following $\left(\tilde{g}_{1}, \ldots, \tilde{g}_{i-1}\right.$, less differentiation), it anticipates its competitors' costs $\mathbf{c}_{-i L}$ in $\mathcal{L}_{S}$. The firm then picks $\max \left\{0, \pi_{L}\left(c_{i L}, \mathbf{c}_{-i L}\right)-f_{L}, \pi_{D}\left(c_{i D}\right)-f_{D}\right\}$. These decisions are unique in every node up to a perturbation of parameters, and so the SPE is also unique up to a perturbation. Throughout, we ignore these cases of indifference and cases in which two or more firms have the same unit $\operatorname{cost} c_{i L}$ or $c_{i D}$.

Aggregation and Equilibrium Sector $S$ is characterized by unit costs $\left\{c_{i L}, c_{i D}\right\}_{i \in S}$. Assume these cost vectors are bounded below by some $\underline{c}>0$, and ordering firms in ascending $c_{i L}$, they are continuous in $S \in[0,1]$ in all but at most a finite number of sectors in which the number of firms in the sector may change.

All sectors are in SPE. Let $\mathcal{D}_{S}$ be the set of differentiated firms in sector $S$. The set of nests in sector $S$ is one nest $\{i\}$ for each $i \in \mathcal{D}_{S}$ plus $\mathcal{L}_{S}$ if $\mathcal{L}_{S} \neq \emptyset$. Let $\mathbf{c}_{S L}$ be the vector of unit costs in the less-differentiated nest $\mathcal{L}_{S}$, and take $P_{L}\left(\mathbf{c}_{S L}\right)=\infty$ if $\mathcal{L}_{S}=\emptyset$. The price index in $(3)$ is

$$
\bar{P}=\left[\int_{0}^{1}\left[P_{L}\left(\mathbf{c}_{S L}\right)\right]^{1-\eta}+\sum_{i \in \mathcal{D}_{S}}\left(\frac{\eta c_{i D}}{\eta-1}\right)^{1-\eta} d S\right]^{1 /(1-\eta)}
$$


Figure 1: Example of a firm's profit from differentiation and markups $\left(\phi=c_{i D}^{-1}=c_{i L}^{-1}\right)$

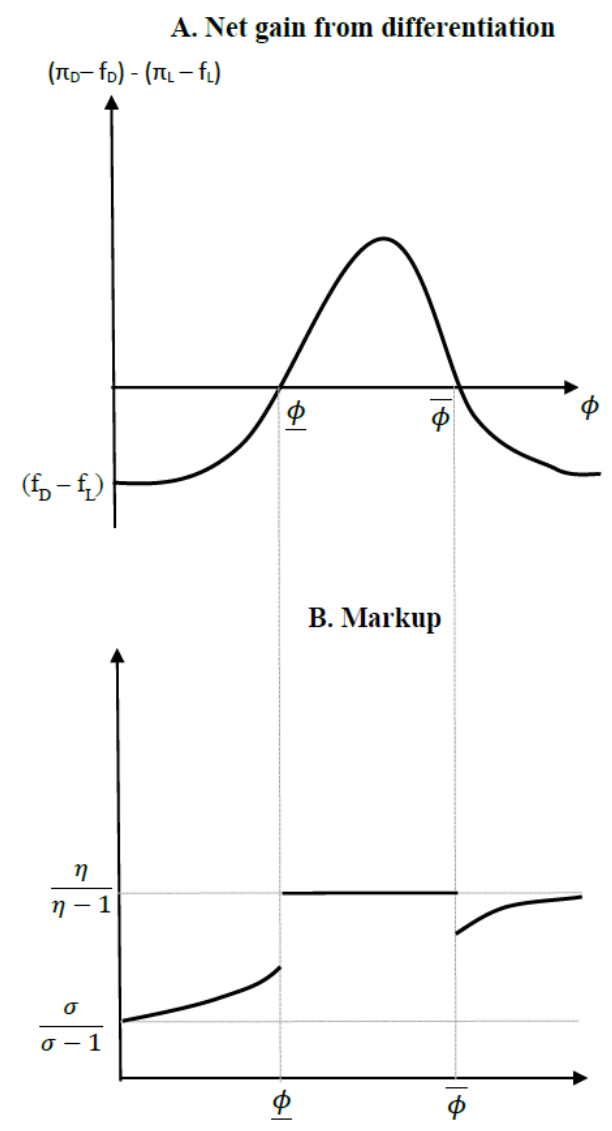

The representative household gets income from wages and profits:

$$
y=1+\int_{0}^{1}\left[\sum_{i \in \mathcal{L}_{S}} \pi_{L}\left(c_{i L}, \mathbf{c}_{-i L}\right)+\sum_{i \in \mathcal{D}_{S}} \pi_{D}\left(c_{i D}\right)\right] d S
$$

Given the assumptions on costs, the integrals in (8) and (9) exist when all sectors are in SPE. An equilibrium is a set of firm strategies, a price $\bar{P}$, and an income $y$ such that all sectors are in subgame perfect equilibrium, and equations (8) and (9) hold.

\subsection{Positive Results in the Closed Economy}

Exit Because more productive firms move first, if firms in sector $S$ can be ranked in terms of costs, $c_{i D}<c_{i^{\prime} D}$ if and only if $c_{i L}<c_{i^{\prime} L}$, then there exists $\bar{c}_{S}>0$ such that firms in $S$ produce if and only if $c_{i L} \leq \bar{c}_{S}$. (See proof in Appendix A.1.) 
Productivity and Differentiation The effect of changes in unit costs on the profit gain from differentiation is straightforward: An efficient firm disproportionately gains if $c_{i D}<c_{i L}$ and loses if $c_{i D}>c_{i L} .{ }^{12}$ So to isolate the novel mechanism, assume for the moment $c_{i D}=c_{i L} \equiv(\phi)^{-1}$ and $f_{D}>f_{L}$ (to make the firm's choice non-trivial). Fix the cost of firm $i$ 's competitors in $\mathcal{L}_{S}, \mathbf{c}_{-i L}$, and vary the firm's productivity $\phi$.

Figure 1 illustrates this exercise. It plots the net profit from differentiation $\pi_{D}(1 / \phi)-$ $\pi_{L}\left(1 / \phi, \mathbf{c}_{-i L}\right)-\left(f_{D}-f_{L}\right)$ in Panel A and markups in Panel B as functions of $\phi$. The net profit is $\left(f_{L}-f_{D}\right)<0$ when $\phi=0$ because $\lim _{\phi \rightarrow 0} \pi_{D}(1 / \phi)=\lim _{\phi \rightarrow 0} \pi_{L}\left(1 / \phi, \mathbf{c}_{-i L}\right)=0$. Appendix A.2 proves convexity of the set of productivities $\phi$ with a positive net profit.

The limit $\phi \rightarrow \infty$ is more didactic. It's less straightforward because the markup gain from differentiation goes to zero but sales go to infinity. Let $p_{i D}=\eta /[(\eta-1) \phi]$ be the price under differentiation, and $P_{-i L}$ be the CES price index in nest $\mathcal{L}_{S}$ excluding firm $i$ from the sum, where we omit its argument $\left(1 / \phi, \mathbf{c}_{-i L}\right){ }^{13}$ Then

$$
\begin{aligned}
\pi_{D}\left(c_{i}\right) & =\frac{y \bar{P}^{\eta-1}}{\eta} p_{i D}^{1-\eta} \\
& \leq \frac{y \bar{P}^{\eta-1}}{\eta}\left(P_{-i L}^{1-\sigma}+p_{i D}^{1-\sigma}\right)^{\frac{\sigma-\eta}{1-\sigma}} P_{-i L}^{1-\sigma}+\frac{y \bar{P}^{\eta-1}}{\eta}\left(P_{-i L}^{1-\sigma}+p_{i D}^{1-\sigma}\right)^{\frac{\sigma-\eta}{1-\sigma}} p_{i D}^{1-\sigma} \\
& \leq \frac{y \bar{P}^{\eta-1}}{\eta}\left(P_{-i L}^{1-\sigma}+p_{i D}^{1-\sigma}\right)^{\frac{\sigma-\eta}{1-\sigma}} P_{-i L}^{1-\sigma}+\pi_{L}\left(1 / \phi, \mathbf{c}_{-i L}\right) .
\end{aligned}
$$

The second line is the operating profit of a hypothetical, differentiated firm that charges $\left[P_{-i L}^{1-\sigma}+p_{i D}^{1-\sigma}\right]^{\frac{1}{1-\sigma}} \leq p_{i D}$ and gets a share $1 / \eta$ of revenue as profits. The third line comes from profit maximization of the less-differentiated firm. Both inequalities hold strictly if $\mathcal{L}_{S} \neq\{i\}$. Rearranging and taking limits,

$$
\lim _{\phi \rightarrow \infty}\left[\pi_{D}(1 / \phi)-\pi_{L}\left(1 / \phi, \mathbf{c}_{-i L}\right)\right] \leq \lim _{p_{i D} \rightarrow 0} \frac{y \bar{P}^{\eta-1}}{\eta}\left(P_{-i L}^{1-\sigma}+p_{i D}^{1-\sigma}\right)^{\frac{\sigma-\eta}{1-\sigma}} P_{-i L}^{1-\sigma}=0 .
$$

In words, the profit gain from differentiation is bounded above by the profit from acquiring the residual demand of competitors in nest $\mathcal{L}_{S}$. Since this residual demand goes to zero as the firm's own productivity goes to infinity, the gain must also go to zero.

\footnotetext{
${ }^{12}$ Innovation is often modelled as a fixed cost to decrease unit costs - e.g, Lileeva and Trefler (2010) and Bustos (2011). Differentiation involves the same considerations in the special case $f_{D}>f_{L}$ and $c_{i D}<c_{i L}$. We deal with the cases $c_{i L} \gtrless c_{i D}$ in Appendix A.2.

$$
P_{-i L}=\left(\sum_{i^{\prime} \in \mathcal{L}, i^{\prime} \neq i} p_{i^{\prime}}^{1-\sigma}\right)^{\frac{1}{1-\sigma}}
$$

where prices $p_{i^{\prime}}$ are implicitly defined in (5) when costs in $\mathcal{L}_{S}$ are $\left(1 / \phi, \mathbf{c}_{-i L}\right)$.
} 
Shocks to Competition in a Sector Sector $S$ is initially in SPE. A shock decreases the unit $\operatorname{cost} c_{i L}$ of some firm $i \in S$. The sector moves to a new SPE.

In profit function (4), the key statistic summarizing the level of competition that firm $i$ faces in the less-differentiated nest is

$$
P_{-, L}\left(c_{i L}, \mathbf{c}_{-i L}\right)=\left(\sum_{i^{\prime} \in \mathcal{L}_{S}, i^{\prime} \neq i} p_{i^{\prime}}^{1-\sigma}\right)^{1 /(1-\sigma)} .
$$

where $p_{i^{\prime}}$ are implicit functions of costs through (5). We refer to a decrease in $c_{i L}$ as large if it decreases $P_{-, L}\left(c_{i^{\prime} L}, \mathbf{c}_{-i^{\prime} L}\right)$ for all $i^{\prime} \neq i$ and $i^{\prime} \in S$. With a finite number of firms per sector, it's always possible to construct large shocks.

A large decrease in $c_{i L}$ increases differentiation and exit among firms $i^{\prime} \neq i$ and $i^{\prime} \in$ $S$. Among surviving firms, the shock decreases the markup of firms that remain less differentiated, and it increases the markup of newly-differentiated firms.

Take two firms $a, b \in \mathcal{L}_{S}$ in the initial equilibrium with $c_{a L}<c_{b L}$. If both firms survive and make the same discrete choice after the shock, then the markup of $b$ increases relative to $a$. This result holds when both firms differentiate because firm $a$ initially has a higher markup than $b$, and their markups both go to $\eta /(\eta-1)$. Appendix A.3 proves the case in which firms $a$ and $b$ remain in $\mathcal{L}_{S}$, and they best respond to the shock and to other endogenous price changes. Intuitively, firm $b$ has less scope to decrease its markup, which is closer to the lower bound $\sigma /(\sigma-1){ }^{14}$

Appendix A.4 uses a numerical example to show that a small decrease in $c_{i L}$ has an ambiguous effect on the discrete choice of firms in $S$ due to strategic interactions among firms. The example has three firms. Firms 1 and 3 are initially less-differentiated. Firm 2 is differentiated because its entry into nest $\mathcal{L}_{S}$ is not enough to induce firm 3 to exit and $\pi_{D}\left(c_{2 D}\right)>\pi_{L}\left(c_{2 L},\left\{c_{1 L}, c_{3 L}\right\}\right)$. A shock decreases cost $c_{1 L}$ to $c_{1 L}^{\prime}<c_{1 L}$. Firm 3 then prefers to exit then to compete with both firms 1 and 2 in nest $\mathcal{L}_{S}$. In response to the change in firm 3's strategy, firm 2 switches from differentiation in the initial equilibrium to less differentiation, because $\pi_{D}\left(c_{2 D}\right)<\pi_{L}\left(c_{2 L},\left\{c_{1 L}^{\prime}\right\}\right)$. In this example, $P_{-, L}\left(c_{2 L}, \mathbf{c}_{-2 L}\right)$ in (10) increases with the shock as $\mathbf{c}_{-2 L}$ goes from $\left\{c_{1 L}, c_{3 L}\right\}$ to $\left\{c_{1 L}^{\prime}\right\}$.

Shock to Competition in a Non-Zero Measure of Firms. Let $\mathcal{I}$ be a set of firms and $\mathcal{S}$ be the smallest subset of sectors containing $\mathcal{I}$. Assume $\mathcal{S}$ has a non-zero measure. An economy is in equilibrium. The unit $\operatorname{cost} c_{i L}$ of all firms $i \in \mathcal{I}$ decreases. The assumptions on continuity and boundedness of the cost vectors hold before and after

\footnotetext{
${ }^{14}$ This result extends Amiti et al. (2014) who prove that markup responses are increasing in firm size for a marginal shock to a firm's cost in the Atkeson and Burstein (2008) model.
} 
the shock. The economy adjusts to a new equilibrium.

Assume that the shock is large enough to decrease $\bar{P}^{\eta-1} y$ and to decrease $P_{-, L}\left(c_{i L}, c_{-i L}\right)$

for all firms $i \in \mathcal{S} \backslash \mathcal{I}$. A large shock decreases $\bar{P}^{\eta-1} y$ because the profit share of the economy is bounded, and the shock can make $\bar{P}$ arbitrarily small. It satisfies the second condition because the number of firms in each sector is finite. ${ }^{15}$

For firms $i \in \mathcal{S} \backslash \mathcal{I}$, the shock increases exit, and it increases differentiation if $f_{D} \leq f_{L}$. The effect of the shock on the ratio $\pi_{D}\left(c_{i D}\right) / \pi_{L}\left(c_{i L}, c_{-i L}\right)$ is the same as in the single-sector shock above. The condition $f_{D} \leq f_{L}$ arises because profits $\pi_{D}$ and $\pi_{0}$ both fall with the fall in $\bar{P}^{\eta-1} y$. Then, the incentives for firms to make costly investments decreases, as in standard models.

In sum, firms in the model have an option to escape competition by creating a new nest. The net profit from this option is not necessarily monotonic in firm productivity, and it increases with large shocks to competition among less-differentiated varieties. Next, we compare this private profit to social welfare.

\subsection{Welfare Results in the Closed Economy}

It is well-known that heterogeneous markups lead to factor misallocation. Appendix B.1 proves that, given a set of discrete choices, the planner allocates relatively more labor than the market to differentiated than to less-differentiated varieties, and to more productive varieties within less-differentiated nests. ${ }^{16}$ Here, we focus on novel results on discrete choices. We evaluate the marginal welfare effects of a single variety in Section 2.2.1 and of a non-zero mass of firms in Section 2.2.2.

\subsubsection{Marginal Welfare Effect of a Firm's Discrete Choice}

Removing a variety from the market frees up labor to the rest of the economy. The marginal cost of labor in the economy is $C=K / Q$ where $Q$ is the standard aggregate

\footnotetext{
${ }^{15}$ A large shock may drive all firms out of the market in some sectors, including firms directly hit with the shock, due to the reduction in $\bar{P}^{\eta-1} y$. This possibility does not affect any of the claims below.

${ }^{16}$ See Edmond et al. (2015) for misallocation in the Atkeson and Burstein (2008) model (with exogenous nests). From standard CES maximization, labor allocations of any $i, i^{\prime} \in \mathcal{L}_{S}$ satisfy

$$
\frac{\text { labor poner }_{i}^{\text {planner }}}{\text { labor }_{i^{\prime}}^{\text {planner }}}=\left(\frac{c_{i L}}{c_{i^{\prime} L}}\right)^{-\sigma}>\left(\frac{c_{i L} / \mu_{i L}}{c_{i^{\prime} L} / \mu_{i^{\prime} L}}\right)^{-\sigma}=\frac{\text { labor }_{i}^{\text {market }}}{\text { labor }_{i^{\prime}}^{\text {market }}}
$$

So, the planner allocates more labor to the variety with the higher markup $\mu_{i L}$ compared to the market. The proof for allocation of labor between nests follows a similar reasoning.
} 


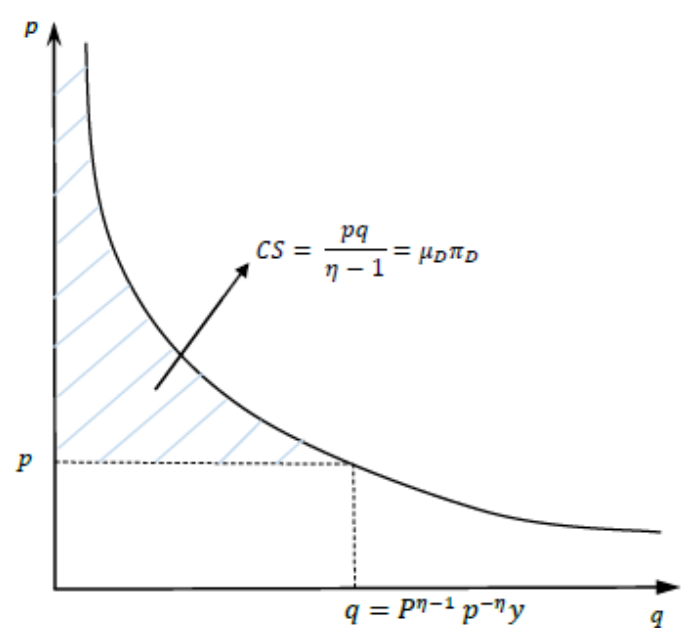

(a) Differentiated Variety

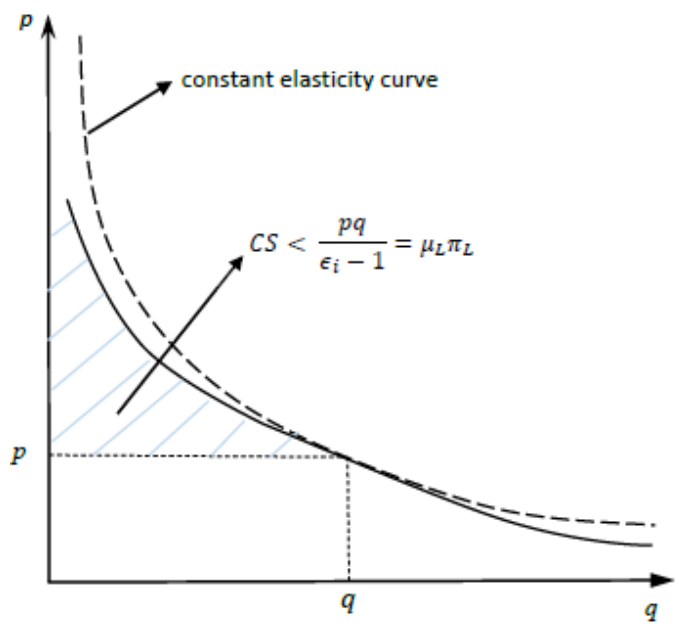

(b) Less-Differentiated Variety

Figure 2: Consumer surplus terms (CS) in equations (11) and (13)

quantity, $Q=y / \bar{P}$, and $K$ is labor allocated for production:

$$
K=1-\int_{0}^{1}\left(\left|\mathcal{L}_{S}\right| f_{L}+\left|\mathcal{D}_{S}\right| f_{D}\right) d S
$$

where $|x|$ denotes the number of elements in set $x$. Define the average markup as $\bar{\mu}=\bar{P} / C$, price over marginal cost.

Denote the differentiated markup with $\mu_{D}=\eta /(\eta-1)$. By Roy's identity, the value of a differentiated variety $i \in \mathcal{D}_{S}$ to the planner is:

$$
\begin{aligned}
u_{D}\left(c_{i D}\right) & =\bar{P}^{-1} \underbrace{\int_{\mu_{D} c_{i}}^{\infty} q(p,\{i\}) d p}_{\text {consumer surplus }}-C^{-1} f_{D} \\
& =\bar{P}^{-1} \mu_{D} \pi_{D}\left(c_{i D}\right)-C^{-1} f_{D} \\
& =C^{-1}\left[\left(\frac{\mu_{D}}{\bar{\mu}}\right) \pi_{D}\left(c_{i D}\right)-f_{D}\right] \\
& \geq C^{-1}\left[\pi_{D}\left(c_{i D}\right)-f_{D}\right] .
\end{aligned}
$$

where the second line uses $q(p,\{i\})=y \bar{P}^{\eta-1} p^{-\eta}$ from (1). Figure 2(a) illustrates the consumer surplus term. 
Also in (1), the demand for a less-differentiated variety $i \in \mathcal{L}_{S}$ is

$$
q_{L}\left(p, \mathcal{L}_{S}\right)=\bar{P}^{\eta-1} y\left(p^{1-\sigma}+\sum_{i^{\prime} \in \mathcal{L}_{S}, i^{\prime} \neq i}\left(p_{i^{\prime}}\right)^{1-\sigma}\right)^{\frac{\sigma-\eta}{1-\sigma}} p^{-\sigma}
$$

Define function $\tilde{q}_{i}(p)=A p^{-\epsilon}$ where $\epsilon$ is the endogenous elasticity of demand of the firm in equilibrium, and constant $A$ satisfies $\tilde{q}_{i}\left(\mu_{i L} c_{i L}\right)=q_{L}\left(\mu_{i L} c_{i L}, \mathbf{p}_{-i L}\right)$ where $\mu_{i L}=\epsilon /(\epsilon-1)$. Figure 2(b) illustrates $\tilde{q}_{i}$ and $q_{L}$. The dashed line of $\tilde{q}_{i}(p)$ is above the solid line of $q\left(p^{\prime}, \mathcal{L}_{S}\right)$, because the elasticity of demand in $(5)$ is strictly increasing in the firm's price. The contribution of variety $i$ to welfare satisfies

$$
\begin{aligned}
u_{L}\left(c_{i L}, \mathbf{c}_{-i L}\right) & \leq \bar{P}^{-1} \underbrace{\int_{\mu_{i L} c_{i L}}^{\infty} q\left(p^{\prime}, \mathcal{L}_{S}\right) d p^{\prime}}_{\text {consumer surplus }}-C^{-1} f_{L} \\
& \leq \bar{P}^{-1} \int_{\mu_{i L} c_{i L}}^{\infty} \tilde{q}_{i}\left(p^{\prime}\right) d p^{\prime}-C^{-1} f_{L} \\
& =C^{-1}\left[\frac{\mu_{i L}}{\bar{\mu}} \pi_{L}\left(c_{i L}, \mathbf{c}_{-i L}\right)-f_{L}\right] .
\end{aligned}
$$

The first inequality holds because when variety $i$ is taken out of nest $\mathcal{L}_{S}$, the consumer's valuation of other varieties in $\mathcal{L}_{S}$ increases. The second inequality is area between $q_{L}$ and $\tilde{q}$ in Figure 2(b). ${ }^{17}$ Both inequalities are strict if $\mathcal{L}_{S} \neq\{i\}$.

Since $\mu_{D} \geq \mu_{i L}$, inequalities (12) and (14) imply that the marginal social benefit of a differentiated variety is always greater than the private profit, whether the comparison is to exit or less differentiation. Compared to exit, the social benefit of a less-differentiated variety is smaller than the private profit if the firm is sufficiently less productive than its competitors for $\mu_{i L}<\bar{\mu}$.

In sum, there are three reasons for the planner to value differentiated varieties more than the market. First, less-differentiated varieties steal business from each other (inequality (13)). Second is the wedge between the two curves in Figure 2(b). Third, the consumer surplus is calculated on the basis of prices and quantities, but the planner values labor. And for a given revenue, the differentiated variety uses less labor because it has a higher markup (inequality (12)).

\footnotetext{
${ }^{17}$ The area under this dashed line is

$$
\int_{\mu_{i L} c_{i L}}^{\infty} A p^{-\epsilon} d p=\frac{A\left(\mu_{i L} c_{i L}\right)^{-\epsilon+1}}{\epsilon-1}=\frac{\mu_{i L} c_{i L}\left[q_{L}\left(\mu_{i L} c_{i L}, \mathbf{p}_{-i L}\right)\right]}{\epsilon-1}=\mu_{i L} \pi_{L}\left(c_{i L}, \mathbf{c}_{-i L}\right)
$$
}




\subsubsection{Welfare and the Discrete Choices of a Large Set of Firms}

An economy is in equilibrium. A planner selects a set of differentiated firms $\mathcal{I}$, with non-zero mass, and shifts them to less-differentiation. The planner maintains other firms' discrete choices. The conditions on continuity of costs hold conditional on new discrete choices. Simultaneously after the change, all firms reset prices and general equilibrium variables $(\bar{P}, y)$ adjust to satisfy $(8)$ and $(9)$.

We prove that welfare is lower in the counterfactual than in the original equilibrium. Suppose not. Suppose that real income $y / \bar{P}$ increases. Then, $\bar{P}^{\eta-1} y$ must decrease because $y$ decreases by construction. ${ }^{18}$ Then, for any firm $i$,

$$
\begin{aligned}
& \pi_{L}\left(c_{i L}, \mathbf{c}_{-i L}\right)-\pi_{D}\left(c_{i D}\right)= \\
& \bar{P}^{\eta-1} y\left[\frac{1}{\epsilon\left(c_{i L}, \mathbf{c}_{-i L}\right)}\left(\frac{c_{i L} \epsilon\left(c_{i L}, \mathbf{c}_{-i L}\right)}{\epsilon\left(c_{i L}, \mathbf{c}_{-i L}\right)-1}\right)^{1-\sigma} P_{L}\left(\left\{c_{i L}, \mathbf{c}_{-i L}\right\}\right)^{\sigma-\eta}-\frac{1}{\eta}\left(\frac{c_{i D} \eta}{\eta-1}\right)^{\eta-1}\right]
\end{aligned}
$$

decreases because $\bar{P}^{\eta-1} y$ decreases and there are (weakly) more elements in $\mathbf{c}_{-i L}$ for all $i$. But in Section 2.2.1, we proved that the marginal gain from transferring a firm from differentiation to less-differentiation was larger for the firm than for the planner. So, the only way for the planner to benefit from the counterfactual is if the profits from lessdifferentiation increase with general equilibrium effects for a non-zero measure of firms. This contradicts the movement in (15).

\section{A Small Open Economy with Intermediate Inputs}

We introduce international trade and input suppliers to the model. For exposition, we present a highly stylized, partial equilibrium model here and its results in Section 3.1. Appendix $\mathrm{C}$ proves these results in general equilibrium and with free entry. In Section 3.1, we describe these extensions and discuss other assumptions.

Home is a small country that trades with large Foreign. Home households sell their one unit of labor in a perfect labor market. There is a continuum of sectors $S \in[0,1]$. Sector 0 produces a homogenous good using only labor and the same constant returns to scale technology in Home and Foreign. This homogeneous good is traded at no cost. We take wages in Home and Foreign to be the numeraire. Since our empirical focus is on import competition, not exports, we assume that the homogeneous good is used only for

\footnotetext{
${ }^{18}$ The markup strictly decreases for all firms in $\mathcal{I}$ and for their competitors in less-differentiated nests $\mathcal{L}_{S}$. Since the price indices of these nests decrease relative to firms that remain differentiated, labor shifts from differentiated firms to $\mathcal{L}_{S}$.
} 
Figure 3: Summary of firms choices and flows in the Home market

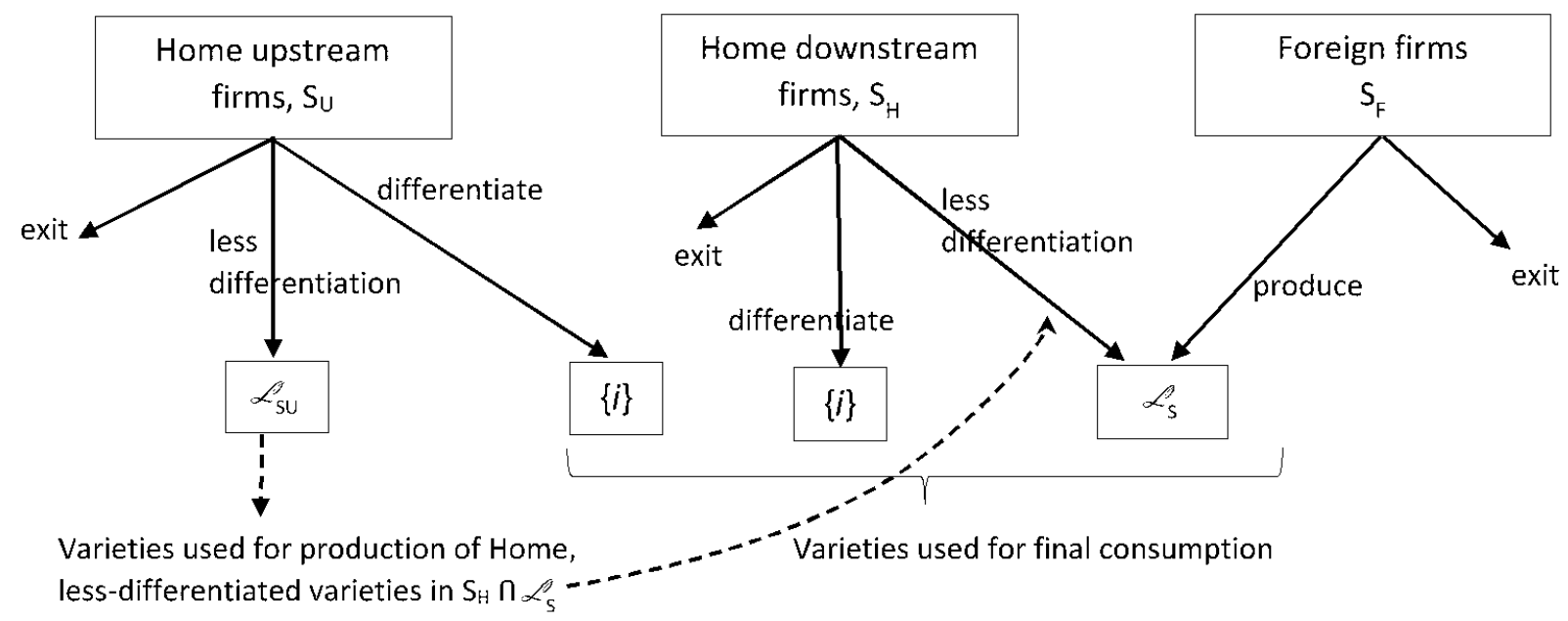

exports to balance trade, not by Home firms or consumers.

Each sector $S \in(0,1]$ is endowed with three finite sets of firms: A set of downstream Foreign firms $S_{F}$, a set of downstream Home firms $S_{H}$, and a set of upstream Home firms $S_{U}$. As before, firms' discrete choices partition the varieties used for final consumption into nests. Consumer demand over these varieties is in (1).

Firms in sector $S \in(0,1]$. Figure 3 summarizes firm choices when servicing the Home market. Each Foreign firm $i \in S_{F}$ chooses between (i) exiting or (ii) supplying Home with a less-differentiated downstream variety. A Home firm $i \in S_{H} \cup S_{U}$ chooses among (i) exiting, (ii) producing a less-differentiated variety, or (iii) producing a differentiated variety. For simplicity, all differentiated varieties in $S_{H} \cup S_{U}$ are used for final consumption and each has its own nest. All less-differentiated downstream varieties, foreign and domestic, are in the same nest $\mathcal{L}_{S}$. All less-differentiated upstream varieties are in nest $\mathcal{L}_{S U}$ and are used for the production of Home less-differentiated varieties in $\mathcal{L}_{S} \cap S_{H}$.

Firms that exit get zero profits. Foreign firm $i \in \mathcal{L}_{S} \cap S_{F}$ pays a fixed cost $f_{L}^{*}$ and a cost $c_{i L}$ for each unit of its variety delivered in Home. A Home differentiated firm $i$ pays a fixed cost $f_{D}$ and its unit cost is $c_{i D}$. A less-differentiated upstream variety $i \in \mathcal{L}_{S U}$ has a fixed cost $f_{U}$ and unit cost $c_{i U}$. Less-differentiated domestic downstream varieties, in $\mathcal{L}_{S} \cap S_{H}$, have a fixed cost of $f_{L}$ units of labor, and they combine labor with less-differentiated upstream varieties in $\mathcal{L}_{S U}$ for variable costs. The unit cost of firm $i \in \mathcal{L}_{S} \cap S_{H}$ is $c_{i L}=\tilde{c}_{S U} / \phi_{i}$ where $\phi_{i}$ is a firm-specific productivity parameter and $\tilde{c}_{S U}$ is 
the cost of an input bundle:

$$
\tilde{c}_{S U}=\left(\left(p_{S U}\right)^{1-\eta_{U}}+1\right)^{1 /\left(1-\eta_{U}\right)}
$$

where

$$
p_{S U}=\left(\sum_{i \in \mathcal{L}_{S U}} p_{i}^{1-\sigma_{U}}\right)^{1 /\left(1-\sigma_{U}\right)}
$$

and $\sigma_{U}>\eta_{U}>1$

Game in sector $S \in(0,1]$. The sectoral game has the following stages. (1) In ascending order of $\operatorname{costs} c_{i U}$, Home upstream firms in $S_{U}$ make their discrete choices. (2) In ascending order of costs $c_{i L}$, Foreign firms in $S_{F}$ make their discrete choices. (3) In descending order of productivity $\phi_{i}$, Home downstream firms in $S_{H}$ make their discrete choices. (4) All firms set prices simultaneously. (5) Production and sales take place, and payoffs are realized.

The ordering of stages 1,2 , and 3 do not matter for the results. Prices are set last so that firms cannot commit on prices to manipulate other firms' discrete choices. We again consider the subgame perfect equilibrium.

In the pricing stage, since firms best respond to each other's prices, downstream firms take as given input cost $\tilde{c}_{S U}$ and the vector of $\operatorname{costs} c_{i L}$ for Home and Foreign firms in $\mathcal{L}_{S}$. The net profit of a firm $i \in \mathcal{L}_{S}$ is $\left[\pi_{L}\left(c_{i L}, \mathbf{c}_{-i L}\right)-f_{L}\right]$ if $i \in S_{H}$ and $\left[\pi_{L}\left(c_{i L}, \mathbf{c}_{-i L}\right)-f_{L}^{*}\right]$ if $i \in S_{F}$, where function $\pi_{L}$ is in (7). The net profit of a differentiated firm $i$ is $\pi_{D}\left(c_{i D}\right)-f_{D}$, where $\pi_{D}$ is in $(6)$.

The total production cost of all less-differentiated downstream Home firms, in $\mathcal{L}_{S} \cap S_{H}$, is $Y_{S U} \tilde{c}_{S U}$ where

$$
Y_{S U}=\bar{P}^{\eta-1} y P_{L}^{\sigma-\eta}\left(\sum_{i \in \mathcal{L}_{S} \cap S_{H}} p_{i}^{-\sigma} / \phi_{i}\right)
$$

is a demand shifter that input suppliers take as given. Using (16), a firm in $\mathcal{L}_{S U}$ with cost $c$ has operating profit

$$
\max _{p} Y_{S U}\left(\tilde{c}_{S U}\right)^{\eta_{U}}\left(p_{S U}\right)^{\sigma_{U}-\eta_{U}} p^{-\sigma_{U}}(p-c)
$$

subject to (16). From the first order conditions, its markup is $\epsilon_{U} /\left(\epsilon_{U}-1\right)$ where

$$
\epsilon_{U}=\sigma_{U}(1-s)+\eta_{U} s\left(1-s_{S U}\right)
$$


and where

$$
\begin{aligned}
s_{S U} & =\left(\frac{p_{S U}}{\tilde{c}_{S U}}\right)^{1-\eta_{U}}, \\
s & =\left(\frac{p}{p_{S U}}\right)^{1-\sigma_{U}} .
\end{aligned}
$$

Endogenous elasticity $\epsilon_{U}$ is again a weighted average of elasticities. The firm's market share in nest $\mathcal{L}_{S U}$ is $s$. If $s$ is small, its elasticity is close to $\sigma_{U}$, the elasticity of substitution among varieties in $\mathcal{L}_{S U}$. If $s$ is large, then it competes with labor with an elasticity $\eta_{U}$. The share of the firm in total costs $\tilde{c}_{S U}$ is $s s_{S U}$. If $s s_{S U}=1$ the firm would face an elasticity zero because it takes sales downstream as given. To eliminate this possibility, ensure that problem (18) has a solution and that markups increase with differentiation, assume that $\operatorname{cost} c_{i U}$ is sufficiently high that the elasticity $\epsilon_{U}>\eta$ whenever $s=1$ for all $i \in S_{U}$ and all $S \in(0,1] .{ }^{19}$

Equation (19) implicitly defines the vector of prices in nest $\mathcal{L}_{S U}$ as a function of unit $\operatorname{costs} c_{i U}$. The operating profit (18) of firm $i \in \mathcal{L}_{S U}$ is

$$
\pi_{U}\left(c_{i U}, \mathbf{c}_{-i U}, Y_{S U}\right)=Y_{S U}\left(\tilde{c}_{S U}\right)^{\eta_{U}}\left(p_{S U}\right)^{\sigma_{U}-\eta_{U}}\left(\frac{\epsilon_{U} c_{i U}}{\epsilon_{U}-1}\right)^{-\sigma_{U}}
$$

where $\mathbf{c}_{-i U}$ is the vector of its competitors' costs, and we omitted the arguments of functions on the right-hand side. Elasticity $\epsilon_{U}$ and price indices $\tilde{c}_{S U}$ and $p_{S U}$ are functions of $\left(c_{i U}, \mathbf{c}_{-i U}\right)$, and $Y_{S U}$ is a function of input cost $p_{S U}$ and of the parameters of downstream firms in $\mathcal{L}_{S},\left\{\phi_{i}\right\}_{i \in \mathcal{L}_{S} \cap S_{H}}$ and $\left\{c_{i L}\right\}_{i \in \mathcal{L}_{S} \cap S_{F}}$. The firm's net profit is $\pi_{U}\left(c_{i U}, \mathbf{c}_{-i U}, Y_{S U}\right)-f_{U}$. This completes the derivation of payoffs in all final nodes of the sectoral game.

Equilibrium discrete choices are again solved by backward induction. Each firm effectively chooses among subgames when making its discrete choice, and the SPE is unique up to a perturbation of parameters.

Because upstream firms move first, there may be strategic complementarities among them. A firm may enter $\mathcal{L}_{S U}$ only in subgames with a sufficiently large set of competitors in $\mathcal{L}_{S U}$ to drive down equilibrium cost $\tilde{c}_{S U}$ and induce downstream entry into $\mathcal{L}_{S}$.

Equilibrium of Open-Economy Model with Inputs We uphold the previous assumptions on continuity and lower bound of cost parameters $c_{i L}$ for $i \in S_{F}$, and $c_{i U}$ for $i \in S_{U}, c_{i D}$ for $i \in S_{U} \cup S_{H}$, and $\left(1 / \phi_{i}\right)$ for $i \in S_{H}$. An equilibrium is a set of firm

\footnotetext{
${ }^{19} \mathrm{~A}$ sufficient condition is $\eta<\eta_{U}$ and all $c_{i U}>\underline{c}_{U}$ where $\underline{c}_{U}>0$ satisfies $\eta_{U}\left[1-\left(\underline{c}_{U}^{1-\eta_{U}} /\left(1+\underline{c}_{U}^{1-\eta_{U}}\right)\right)\right]>\eta$. In Appendix C.4, upstream firms set prices before downstream firms. Then, they internalize the effect of their prices on sales downstream, obviating the need for this assumption.
} 
strategies and a vector $(y, \bar{P})$ such that firm strategies are subgame perfect in all sectors $S \in(0,1]$, price $\bar{P}$ satisfies (8) and income $y$ satisfies

$$
y=1+\int_{0}^{1}\left[\sum_{i \in \mathcal{L}_{S U}} \pi_{U}\left(c_{i U}, \mathbf{c}_{-i U}, Y_{S U}\right)+\sum_{i \in \mathcal{D}_{S}} \pi_{D}\left(c_{i D}\right)+\sum_{i \in \mathcal{L}_{S} \cap S_{H}} \pi_{L}\left(c_{i L}, \mathbf{c}_{-i L}\right)\right] d S
$$

\subsection{Shocks to International Trade}

Sectoral Shocks An economy is in equilibrium. Trade costs decrease in sector $S$, and all firms in $S$ change their strategies to a new SPE.

A decrease in trade costs in sector $S$ decreases $c_{i L}$ for all $i \in S_{F}$, since these unit costs include production and trade. For domestic downstream firms in $S_{H}$, if the shock is sufficiently large, then it increases exit and differentiation. It increases the markup of firms that differentiate and decreases the markup of firms that remain in $\mathcal{L}_{S}$. If two firms $a, b \in S_{H}$ with $c_{a L}<c_{b L}$ are initially less-differentiated, then the markup of firm $b$ increases relative to firm $a$ if both firms remain in $\mathcal{L}_{S}$ or if they both differentiate.

To see that these results from Section 2.1 hold even with input suppliers, note that the cost of the bundle of inputs $\tilde{c}_{S U}$ is bounded below by the cost when all upstream firms $i \in S_{U}$ are less-differentiated. Then, it is always possible to decrease $c_{i L}$ for all $i \in S_{F}$ sufficiently for $P_{-, L}$ in (10) to decrease for all domestic firms $i$ relative to the firm's unit cost when the input bundle is at its lower bound.

For upstream firms, the shock decreases the absorption of less-differentiated inputs, directly through losses in the market share of downstream domestic firms in $\mathcal{L}_{S} \cap S_{H}$ and indirectly through exit and differentiation downstream. As $c_{i L}$ goes to zero for all $i \in S_{F}$, the term $Y_{S U}$ in (17) and the profit a less-differentiated input supplier also go to zero. Hence, for a sufficiently large shock, upstream firms also exit or differentiate. These changes by some firms increase the market share of upstream firms that remain less-differentiated, in $\mathcal{L}_{S U}$. Hence their markups in (19) increase.

Economy-Wide Shocks A large reduction in Foreign costs in a non-zero measure of sectors $\mathcal{S} \subset(0,1]$ increases exit and differentiation of Home firms in sectors $S \in \mathcal{S}$ if $f_{D} \leq f_{L}$. Suppose that after the shock, a planner forces downstream Home firms to switch back to less-differentiation and maintains other firms' post-trade discrete choices. The results on welfare in Section 2.2 imply that the economy is worse off after the planner's intervention than in the post-trade equilibrium. In this sense, the welfare gains from trade are larger in the model than in a standard model without the option of differentiation. ${ }^{20}$

\footnotetext{
${ }^{20}$ See Appendix C.2 for the welfare proof in the open economy.
} 
Discussion Two assumptions are worth noting. First, foreign firms cannot differentiate their variety. Nothing in the model changes if we allow for the existence of nests that are supplied only by foreign firms, such as market niches with luxuries and high-tech goods. ${ }^{21}$ Key is that, for domestic firms, import competition decreases the profit from less-differentiated relative to differentiated varieties. It is consistent with our interpretation, in the introduction, of differentiated domestic varieties as more customized, tailored to domestic tastes, bundled with non-tradable services. Second, less-differentiated inputs are used only for producing less-differentiated downstream output. If product differentiation is associated with quality upgrades, as in the examples of Xiaomi and Chery, then the assumption that lower-quality firms use lower-quality inputs is well grounded in the literature. ${ }^{22}$

Appendix $\mathrm{C}$ proves the results in general equilibrium. In Appendix $\mathrm{C} 1$, there is no homogeneous sector 0 and firms in sectors $S \in(0,1]$ may export. Appendix $\mathrm{C} 2$ considers the assumptions of $\mathrm{C} 1$ with two symmetric countries. Appendix $\mathrm{C} 3$ introduces free entry.

\section{Data and Evidence}

We describe the data in Section 4.1, the empirical specification in Section 4.2, and the results in Section 4.3. Section 4.4 uses the model to interpret these results. We use a similar specification and the same data as Brandt, Van Biesebroeck, Wang, and Zhang (2017, BVWZ henceforth).

\subsection{Data Sources}

We use an annual survey of industrial establishments collected by the Chinese National Bureau of Statistics. The survey comprises private enterprises with annual sales of more than 5 million yuan and all state-owned enterprises (SOEs). We use a ten-year unbalanced panel from 1998 to 2007. The data contain information on output, fixed assets, total workforce, wage bill, intermediate input costs, foreign investment, revenue from domestic and export sales. Price indices by sector are reported annually in the official publication. See BVWZ, Du et al. (2012) and Aghion et al. (2015) for further details.

The original dataset has 2,226,104 establishment-year observations. We keep only firms in manufacturing, the more tradable sector. We drop three sectors with missing price indices, and observations with missing data on output, labor, capital, or material

\footnotetext{
${ }^{21} \mathrm{~A}$ decrease in the price index of these nests has the same general equilibrium effects of decreasing $\bar{P}^{\eta-1} y$ as decreases in the cost of foreign varieties in a non-zero set of sectors.

${ }^{22}$ See Kugler and Verhoogen (2011), DeLoecker et al. (2016) and Fieler et al. (2018).
} 
inputs. Our main results restrict the sample to firms with zero foreign ownership and with zero or a minority state ownership. The results with multinationals and SOE's are in Section 5. The final sample has 1,037,738 observations.

Our tariff data set is the World Integrated Trading Solution (WITS), maintained by the World Bank. We use the 2002 Chinese Input-Output table to construct some variables.

\subsection{Empirical Specification}

Our main regression specification is:

$$
\begin{aligned}
y_{i t}= & \beta_{1} \log \text { Output_Tariff }{ }_{j(i, t) t}+\beta_{2} \log \text { Downstream_Tariff }_{j(i, t) t} \\
& +\gamma_{1} X_{j(i, t) t}+\gamma_{2} X_{i, t}+\alpha_{i}+\alpha_{t}+\varepsilon
\end{aligned}
$$

where the subscripts refer to firm $i$, year $t$, and the sector $j(i, t)$ of firm $i$ at time $t$, $\alpha_{i}$ are firm fixed effects, and $\alpha_{t}$ are time fixed effects. Appendix D.1 details control variables. Sector-time controls $X_{j t}$ include input tariffs, state ownership in sector $j$, and foreign ownership in sector $j$ and in sectors upstream and downstream from $j$. Firmtime controls $X_{i t}$ include zero-one dummy variables indicating whether firm $i$ received subsidies, whether it received a tax holiday, and whether it paid below median interest rates on loans. We cluster standard errors by firm and by the firm's initial sector.

The independent variables of interest are tariffs that China imposes on its imports. Output_Tariff $_{j t}$ is the tariff of sector $j$ at time $t$. Downstream_tariff $j t$ are tariffs on the sectors to which firms in sector $j$ provide inputs:

$$
\text { Downstream_Tariff }_{j t}=\sum_{k \neq j} \delta_{j k} \text { Output_Tariff } k t
$$

where $\delta_{j k}$ is the share of sector $j$ 's production supplied to downstream sector $k$ in the 2002 Chinese Input-Output table. Weights $\delta_{j k}$ do not add up to one because part of output goes to final consumption. Output tariffs are measured at the four-digit level, while downstream tariffs are measured in 71 sectors because the input-output table has a coarser sectoral classification than the firm survey. Downstream tariffs are intended to capture the effect of tariff reductions on the input suppliers of import-competing firms. For example, for a producer of car engines, the output tariffs are tariffs on car engines and downstream tariffs are tariffs on cars. We also control for input tariffs in $X_{j t}$, but the effect of these tariffs is well known and not the focus of our analysis. ${ }^{23}$

\footnotetext{
${ }^{23}$ We take input and output tariffs directly from BVWZ. As BVWZ observe, input tariffs are measured with error in China because its government often refunds tariffs on inputs.
} 
We use instrumental variables to mitigate the concern that firms endogenously influence tariffs through lobbying. Similar to other trade liberalizations, China reduced both the level and the heterogeneity in tariffs. Following the literature, we instrument for input, output and downstream tariffs using the corresponding tariff for the firm in 1998 interacted with a dummy variable equal to one after China entered the WTO. ${ }^{24}$ BVWZ document a strong negative correlation between initial tariffs and changes in tariffs in China, and they confirm that changes in tariffs are uncorrelated with initial sector characteristics and trends in the establishment survey (Figure 3 and Table 1 in BVWZ).

Dependent variables $y_{i t}$ are firm outcomes often associated with innovation or quality upgrading in the literature: Revenue total factor productivity (TFP), introduction of new goods, and skill intensity.

For TFP, we estimate separately for each 2-digit sector the production function

$$
\log X_{i t}=\alpha_{0 j(i, t)}+\alpha_{L j(i, t)} \log L_{i t}+\alpha_{M j(i, t)} \log M_{i t}+\alpha_{K j(i, t)} \log K_{i t}+\mu_{i t}
$$

where $X$ is output, $L$ is number of employees, $K$ is capital, $M$ is material inputs, and $\alpha_{0 j}, \alpha_{L j}, \alpha_{K j}$ and $\alpha_{M j}$ are sector-specific parameters to be estimated. We deflate output and cost variables with the sectoral price indices. ${ }^{25}$ We estimate (21) using the standard two-stage procedure in Olley and Pakes (1996), with OLS and time fixed effects, and following Ackerberg et al. (2015) in Section 5. The estimated TF $P_{i t}$ is the predicted value of $\log X_{i t}-\hat{\alpha}_{L j(i, t)} \log L_{i t}-\hat{\alpha}_{M j(i, t)} \log M_{i t}-\hat{\alpha}_{K j(i, t)} \log K_{i t}$. When TFP is the dependent variable in (20), we add sector fixed effects since TFP is not comparable across sectors.

For the introduction of new goods, we use the share of new products in total sales, reported in the survey, and a dummy variable equal to one if firm $i$ introduces a new product in year $t$ and zero otherwise.

Unfortunately, we only observe the composition of the workforce in the 2004 survey. We define skilled workers as those with a senior-high degree, or a three- or four-year college degree. ${ }^{26}$ We rank sectors according to the share of skilled workers in their labor force in 2004 and use the ranking of sector $j(i, t)$ as the dependent variable $y_{i t}$ in $(20)$. Of the 450 sectors in the data, the least skill-intensive is the production of packaging and bags, and the most skill intensive is a subsector of aircraft manufacturing.

\footnotetext{
${ }^{24}$ See Goldberg et al. (2009), Amiti and Konings (2007), and Attanasio et al. (2004). We can't use the initial tariffs alone as an instrument because our regressions have firm fixed effects.

${ }^{25}$ Output value is deflated by the 29 individual sector ex-factory price indices of industrial products. To deflate material inputs, these 29 sector price indices are assigned to output data using the Chinese input-output table. Capital is defined as the net value of fixed assets, which is deflated by a uniform fixed assets investment index, and labor is a physical measure of the total number of employees.

${ }^{26}$ Changing the educational cutoffs in the definition of skill intensity yields highly correlated measures.
} 


\subsection{Empirical Results}

The main coefficients from regression (20) are in Table 1, and the coefficients on control variables are in Appendix D.1. The coefficients on output tariffs are all negative. They are statistically significant and larger (in absolute value) in the IV than in the OLS specifications, possibly due to firms responding more to the large tariff cuts of the WTO accession than to smaller cuts in other years. The coefficients are also negative in the subsample of only non-exporting firms in columns (5) and (6). So, greater import competition is associated to within-firm increases in revenue TFP, the introduction of new goods, and shifts toward skill-intensive sectors.

Using the IV specification with all establishments in Panel A, a one standard deviation in log of tariffs, around 0.5 , is associated with an increase in revenue TFP by about 2.5 percent $(0.5 \times 0.5)$. In Panel $\mathrm{B}$, it is associated with an increase of 0.8 percentage points in the share of new products in total sales $(0.5 \times-0.0157)$, and with an increase of 2 percentage points in the probability of introducing a new product $(0.5 \times-0.0405)$.

In Panel $\mathrm{C}$, the dependent variable is the ranking of sectors in ascending order of skill intensity. Since all specifications include firm fixed effects, the identification stems from firms switching sectors, approximately 15 percent of firms in the sample. With point estimates ranging from -18 to -26 , a one standard deviation reduction in log tariffs is associated with a movement up the rank of 9 to 13 sectors. Among non-exporting firms, the sector switches with the largest number of firms include switches from cotton and chemical fibers (1761) to textile and garments manufacturing (1810), from steel rolling processing (3230) to the manufacture of metal structures (3411), and from non-ferrous rolling process (3351) to optical fiber and cable manufacturing (3931). All these switches are from lower value-added products or stages of production to higher value-added products, where the scope for differentiation is arguably greater.

The coefficient on downstream tariffs is negative in all IV specifications of Table 1, suggesting that the suppliers of inputs to import-competing firms also respond to tariff cuts by increasing revenue TFP, introducing new goods, switching to skill-intensive four-digit sectors. When the dependent variable measures the introduction of new goods or sectoral skill intensity (Panels B and C), the coefficients are either close to the coefficient on output tariffs, or they are less robust and flip signs in some OLS specifications. Plausibly, input suppliers seem to respond less to tariff cuts than import-competing firms, directly hit with the shock. But when the dependent variable is TFP (Panel A), the coefficients on downstream tariffs are about seven times larger than the coefficients on output tariffs in all IV specifications. This result is robust to numerous checks in Section 5. 


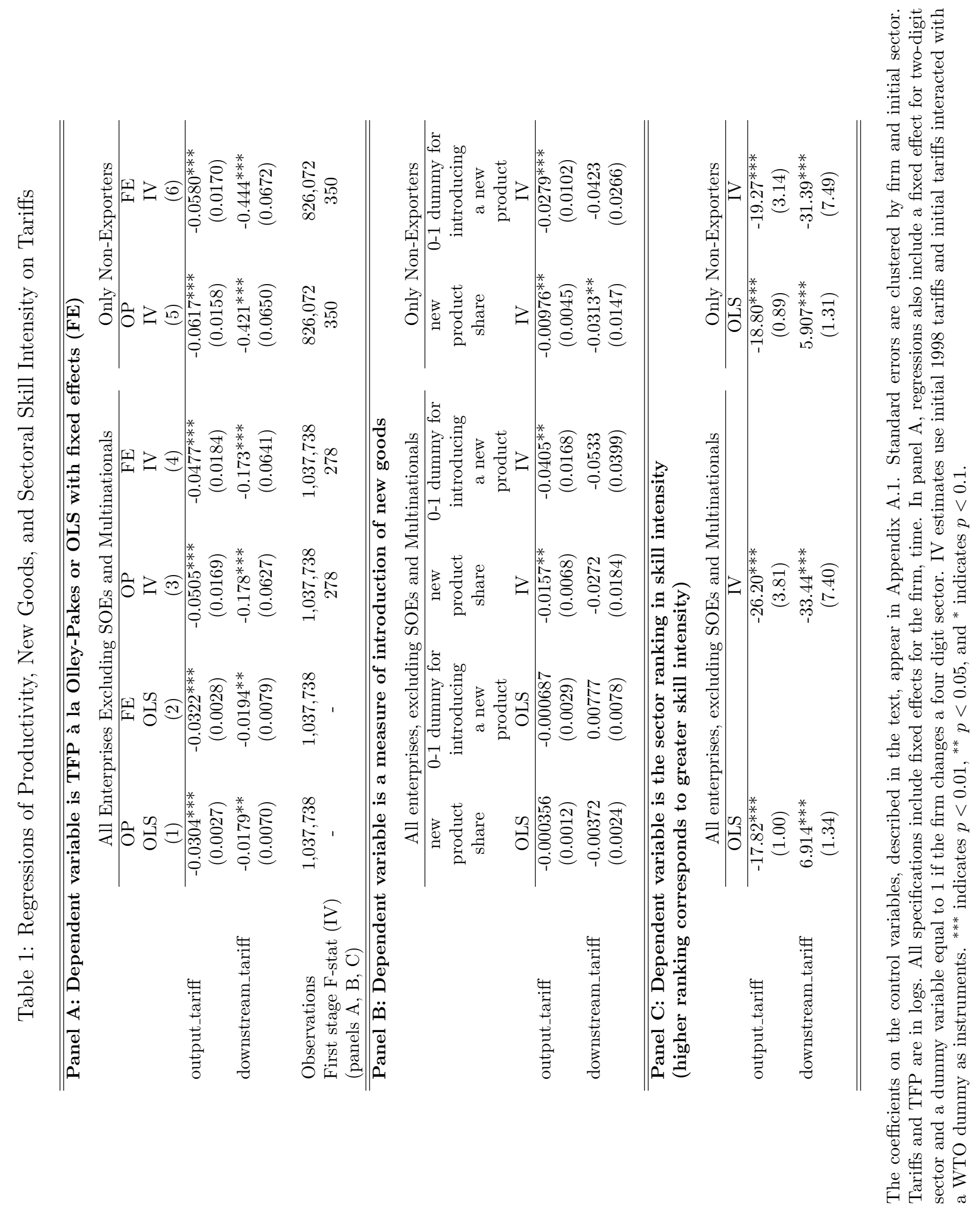


Table 2: Responses of Firms to Output Tariff Cuts by Quartile of Sales

\begin{tabular}{|c|c|c|c|c|c|c|}
\hline \multicolumn{7}{|c|}{ Panel A: Dependent variable is TFP à la Olley-Pakes or OLS with fixed effects (FE) } \\
\hline & \multicolumn{4}{|c|}{ All establishments excl. SOEs and multinationals } & \multicolumn{2}{|c|}{ Only non-exporters } \\
\hline & $\mathrm{OP}$ & $\mathrm{FE}$ & $\mathrm{OP}$ & $\mathrm{FE}$ & $\mathrm{OP}$ & $\mathrm{FE}$ \\
\hline & OLS & OLS & IV & IV & IV & IV \\
\hline tariff* $\mathrm{q}_{i, t-1}$ & $\begin{array}{c}-0.0337^{* * *} \\
(0.00341)\end{array}$ & $\begin{array}{c}-0.0344^{* * *} \\
(0.00350)\end{array}$ & $\begin{array}{c}-0.0334^{* *} \\
(0.0169)\end{array}$ & $\begin{array}{l}-0.0276 \\
(0.0175)\end{array}$ & $\begin{array}{c}-0.0435^{* * *} \\
(0.0167)\end{array}$ & $\begin{array}{c}-0.0365^{* *} \\
(0.0172)\end{array}$ \\
\hline tariff* $\mathrm{q} 2_{i, t-1}$ & $\begin{array}{c}-0.0302^{* * *} \\
(0.00313)\end{array}$ & $\begin{array}{c}-0.0312^{* * *} \\
(0.00322)\end{array}$ & $\begin{array}{l}-0.0277 \\
(0.0179)\end{array}$ & $\begin{array}{l}-0.0249 \\
(0.0189)\end{array}$ & $\begin{array}{c}-0.0396^{* *} \\
(0.0173)\end{array}$ & $\begin{array}{r}-0.0353^{*} \\
(0.0181)\end{array}$ \\
\hline tariff* $\mathrm{q}^{3}{ }_{i, t-1}$ & $\begin{array}{c}-0.0261^{* * *} \\
(0.00314)\end{array}$ & $\begin{array}{c}-0.0273^{* * *} \\
(0.00324)\end{array}$ & $\begin{array}{r}-0.00859 \\
(0.0190)\end{array}$ & $\begin{array}{r}-0.00510 \\
(0.0198)\end{array}$ & $\begin{array}{l}-0.0180 \\
(0.0189)\end{array}$ & $\begin{array}{l}-0.0132 \\
(0.0196)\end{array}$ \\
\hline tariff* $\mathrm{q}{ }_{i, t-1}$ (largest) & $\begin{array}{c}-0.0240^{* * *} \\
(0.00327)\end{array}$ & $\begin{array}{c}-0.0253^{* * *} \\
(0.00340)\end{array}$ & $\begin{array}{l}-0.0129 \\
(0.0168)\end{array}$ & $\begin{array}{l}-0.0118 \\
(0.0178)\end{array}$ & $\begin{array}{l}-0.0259 \\
(0.0173)\end{array}$ & $\begin{array}{l}-0.0233 \\
(0.0182)\end{array}$ \\
\hline $\begin{array}{l}\text { H0: tariff* }{ }^{*} 1<\operatorname{tariff}^{*} q 4 \\
\text { (p-value) }\end{array}$ & 0.0006 & 0.0020 & 0.041 & 0.093 & 0.098 & 0.169 \\
\hline $\begin{array}{l}\text { Observations } \\
\text { (panels A, B, C) }\end{array}$ & 701,765 & 701,765 & 701,765 & 701,765 & 548,283 & 548,283 \\
\hline
\end{tabular}

\begin{tabular}{|c|c|c|c|c|c|c|}
\hline \multicolumn{7}{|c|}{ Panel B: Dependent variable is a measure of introduction of new goods } \\
\hline & \multicolumn{4}{|c|}{ All establishments excl. SOEs and multinationals } & \multicolumn{2}{|c|}{ Only non-exporters } \\
\hline & $\begin{array}{c}\text { new } \\
\text { product } \\
\text { share } \\
\text { OLS }\end{array}$ & $\begin{array}{c}0-1 \text { dummy } \\
\text { for new } \\
\text { product } \\
\text { OLS }\end{array}$ & $\begin{array}{c}\text { new } \\
\text { product } \\
\text { share } \\
\text { IV }\end{array}$ & $\begin{array}{c}0-1 \text { dummy } \\
\text { for new } \\
\text { product } \\
\text { IV }\end{array}$ & $\begin{array}{c}\text { new } \\
\text { product } \\
\text { share } \\
\text { IV }\end{array}$ & $\begin{array}{l}\text { 0-1 dummy } \\
\text { for new } \\
\text { product } \\
\text { IV }\end{array}$ \\
\hline tariff* ${ }^{*} 1_{i, t-1}$ & $\begin{array}{l}0.000531 \\
(0.00144)\end{array}$ & $\begin{array}{l}-0.00138 \\
(0.00348)\end{array}$ & $\begin{array}{r}-0.0152^{* *} \\
(0.00746)\end{array}$ & $\begin{array}{c}-0.0513^{* * *} \\
(0.0184)\end{array}$ & $\begin{array}{l}-0.0123^{* *} \\
(0.00582)\end{array}$ & $\begin{array}{c}-0.0327^{* * *} \\
(0.0124)\end{array}$ \\
\hline $\operatorname{tariff}^{*} \mathrm{q} 2_{i, t-1}$ & $\begin{array}{l}0.000509 \\
(0.00142)\end{array}$ & $\begin{array}{l}0.000862 \\
(0.00328)\end{array}$ & $\begin{array}{r}-0.0169^{* *} \\
(0.00747)\end{array}$ & $\begin{array}{r}-0.0337^{*} \\
(0.0177)\end{array}$ & $\begin{array}{l}-0.0117^{* *} \\
(0.00575)\end{array}$ & $\begin{array}{c}-0.0252^{* *} \\
(0.0120)\end{array}$ \\
\hline tariff* $\mathrm{q} 3_{i, t-1}$ & $\begin{array}{l}0.000192 \\
(0.00153)\end{array}$ & $\begin{array}{c}0.00117 \\
(0.00343)\end{array}$ & $\begin{array}{l}-0.0148^{*} \\
(0.00786)\end{array}$ & $\begin{array}{l}-0.0293 \\
(0.0191)\end{array}$ & $\begin{array}{l}-0.00981 \\
(0.00612)\end{array}$ & $\begin{array}{l}-0.0168 \\
(0.0134)\end{array}$ \\
\hline tariff* $\mathrm{q}_{i, t-1}$ (largest) & $\begin{array}{r}-0.000867 \\
(0.00179)\end{array}$ & $\begin{array}{l}-0.00185 \\
(0.00377)\end{array}$ & $\begin{array}{r}-0.0189^{* *} \\
(0.00834)\end{array}$ & $\begin{array}{l}-0.0264 \\
(0.0194)\end{array}$ & $\begin{array}{r}-0.0131^{* *} \\
(0.00628)\end{array}$ & $\begin{array}{c}-0.0290^{* *} \\
(0.0135)\end{array}$ \\
\hline $\begin{array}{l}\text { H0: tariff* }{ }^{*} 1<\text { tariff* }^{*} 4 \\
\text { (p-value) }\end{array}$ & - & - & - & 0.015 & - & 0.361 \\
\hline
\end{tabular}

Panel C: Dependent variable is the sector ranking in skill intensity (higher ranking corresponds to greater skill intensity)

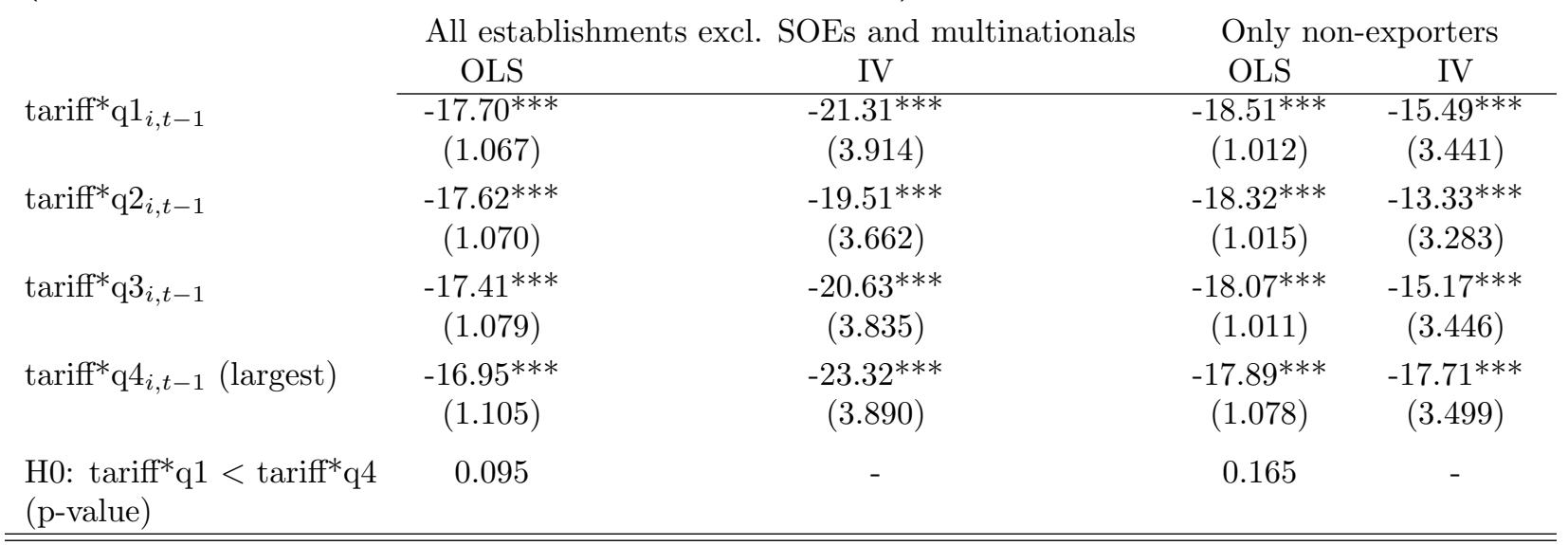

The table repeats the results of Table 1 substituting the independent variable tariff for an interaction of tariff with a dummy indicating the firm's quartile $\mathrm{g}_{3}$ sales in the sector and lagged year (q1, q2, q3, q4) plus the lagged quartiles q1, q2, q3, q4 by themselves. Standard errors are clustered by firm and initial sector. Tariffs and TFP are in logs. Appendix A.1 reports the coefficients on control variables. 
Firm Heterogeneity To investigate whether the responses to tariff cuts differ across firms of different sizes, we split firms in each sector-year into quartiles of sales, and we repeat the regressions in Table 1 replacing log Output_Tariff ${ }_{j(i, t) t}$ with the log Output_Tariff $_{j(i, t) t}$ interacted with dummies indicating the firm's quartile of sales within its sector in year $t-1$. We also add these quartile dummies as independent variables.

Table 2 reports the coefficients on the interaction terms. The dependent variable measures revenue TFP in Panel A, the introduction of new goods in Panel B, and the ranking of sector skill intensity in Panel C. While there is no systematic difference across quartiles of sales in Panels B and $\mathrm{C}$, the coefficient on tariffs increases with quartile of sales in Panel A. It is 40 to 160 percent larger in absolute value in the smallest relative to the largest quartile of sales. This difference is statistically significant in most specifications, as the p-value indicates. ${ }^{27}$

\subsection{Discussion: Data and Model}

Our empirical results exploit cross-sectoral variation of large tariff cuts in China during its WTO accession. We interpret these sector-specific tariff cuts as a reduction in the cost of Foreign varieties $c_{i L}$ in a single sector $S$ in the model. A large reduction increases exit and product differentiation in Home. Since differentiation is not directly observed, we take the introduction of new goods and shifts to skill-intensive four-digit sectors as proxies. Consistent with the model, these variables increase with output tariff cuts in Table 1. In Appendix Tables D.7 and D.8, tariff cuts are associated with exit from the survey and with switches in four-digit sectors (significant in some specifications only). ${ }^{28}$

Revenue TFP in equation (21) is an estimate of the ratio of revenue to costs which corresponds to markups in the model. In Table 1, tariff cuts are associated with smaller increases in the TFP of import-competing firms, directly hit with the shock, than in the TFP of their input suppliers. This result, puzzling at a first sight, is consistent with the model, where import competition downstream increases the markup of upstream firms and has an ambiguous effect on the markup of downstream firms.

In Table 2 Panels B and C, tariff cuts are associated with similar increases in the probability of switching to skill-intensive sectors or of introducing new goods across quartiles of firm sales. This finding suggests that firms of heterogeneous sizes may make similar

\footnotetext{
${ }^{27}$ The coefficients on downstream tariffs almost don't change from Table 1 to 2 (Appendix D.1). In separate regressions, we checked for interactions between quartile of sales and downstream tariffs but found no discernible pattern.

${ }^{28}$ The model doesn't have sharp predictions on the relation between output tariffs and sales, but the relation is generally negative in the data (Table D.9) as predicted by standard models. Table D.10 confirms for our data the well-known positive relation between TFP and sales within sector and year.
} 
discrete choices in response to tariff cuts. The model then predicts that the markup of smaller firms increases relative to larger firms, precisely the monotonic pattern of coefficients across quartiles of sales when the dependent variable is TFP in Panel A.

This interpretation of TFP is valid as long as revenue TFP is correlated with the true unobserved revenue to cost ratio in the data. But two points are in order. First, measures of TFP generally assume a Markov path for productivity, Hicks neutrality, and product homogeneity. These assumptions are all violated in the model and arguably in the data as import competition reshapes firms' residual demand and innovation changes output and production processes. ${ }^{29}$ The usual decomposition of revenue TFP into quantity TFP and prices is not applicable because varieties in the model are differentiated and costs $c_{i L}$ and $c_{i D}$ are quality-adjusted like in Melitz (2003). ${ }^{30}$ Second, even if revenue productivity perfectly measured the ratio of revenue to cost, it would still confound the positive effect of differentiation on markups with the negative effect of tighter competition on firms that do not differentiate.

The Chinese accession to the WTO was a large trade liberalization. Average tariffs on manufacturing in China fell from 43 percent in 1992 to 9.4 percent in 2004. In Table 2, small firms in sectors with larger tariff cuts increased revenue productivity, the introduction of new goods and switches to skill-intensive sectors relative to small firms in other sectors. The model can only rationalize these findings if differentiation doesn't involve large fixed costs, $f_{D} \approx f_{L}$. This condition is sufficient for large and widespread decreases in trade costs to increase differentiation in the model. So, through the lenses of the model, the WTO accession increased overall product differentiation in China, not just in some sectors relative to others.

A back-of-the-envelope calculation suggests that gains from trade due to differentiation may be sizable. In Table 1 Panel B, a one standard deviation reduction in log output tariffs is associated with an increase in new products of 0.8 percentage points in total sales $(0.5 \times-0.0157)$. If we set $\eta=2$ and $\sigma=10$ the welfare gain from increasing the mass of differentiated products by 0.8 percent and decreasing more substitutable products by the same share increases welfare by 0.7 percent, a significant value relative to standard estimates of gains from trade. ${ }^{31}$

\footnotetext{
${ }^{29}$ Harrison (1994), De Loecker (2007) and De Loecker and Warzynski (2012) make similar points on changes in demand during trade reforms. DeLoecker et al. (2016) allow for vertically-differentiated goods, but maintain the other assumptions above. Bøler (2019) and Harrigan et al. (2019) relax Hicks neutrality and allow for skill-biased technical change. We can't use their measurement of TFP because we don't observe worker skills.

${ }^{30}$ As Foster et al. (2008) explain, these methods apply to sectors with homogeneous goods, where quantity TFP is meaningful.

${ }^{31}$ Using the definition of $\bar{P}$ in $(1)$, the estimated decrease in price is $\bar{P}^{1} / \bar{P}^{0} \approx 1.008^{1 /(1-\eta)} *$
} 


\section{$5 \quad$ Robustness of Empirical Results}

Appendix D.3 presents the results and detailed the procedures of the robustness checks summarized here. Checks on Table 1 are in Appendix Tables D.11 (TFP), D.12 (introduction of new goods), and D.13 (sectoral skill intensity). In each table, row 1 has a sample of all firms, including multinationals and SOE's. Rows 2 and 3 check for collinearity by dropping one tariff measure at a time. Rows 4 and 5 check for selection. Row 4 uses only a balanced panel of firms that survived in all ten years of data. Following Wooldridge (2010), we estimate a selection equation with a probit using the accounting profit share of the firm in the previous period as the selection variable. Row 5 repeats the main specification controlling for the estimated Mills ratio. In row 6, we follow Pierce and Schott (2016) in measuring and controlling for the uncertainty in the United States policy toward its imports from China. Row 7 excludes textiles and apparel, the sectors affected by the expiration of the multifiber agreement (MFA) in the period of our data. Row 8 excludes computers and peripherals, which experienced a large growth in offshoring. When the dependent variable is TFP (Table D.11), row 9 includes tariffs in the first stage of the TFP estimation following De Loecker (2007), and row 10 estimates TFP following Ackerberg et al. (2015).

Consistent with Table 1, the coefficient on output tariffs is negative and statistically significant in our preferred specifications, the IV with only non-exporters. When exporters are included, the coefficient loses statistical significance in the specification with multinationals when the dependent variable is TFP (Table D.11, row 1) and with a balanced panel when the dependent variable measures the introduction of new goods (Table D.12, row 4). Both of these results are reassuring. Exporting multinationals are generally not as affected by the domestic market and may have a comparative disadvantage in tailoring their goods to domestic tastes. Firms that survive all ten years of the sample likely have successful products and may be less prone to introduce new ones.

Also consistent with Table 1, when the dependent variable is TFP, the coefficient on downstream tariffs is about seven to eight times larger than the coefficient on output tariffs in all IV specifications with only non-exporters.

Tables D.14, D.15, and D.16 repeat these robustness checks for the specification in Table 2. The coefficient on output tariffs increases systematically with quartile of sales

$0.992^{1 /(1-\sigma)}=0.993$. The value $\eta=2$ is between Edmond et al. (2015)'s estimate $\eta=1.28$ and Broda and Weinstein (2006)'s median elasticity of 5-digit SITC codes, estimated to 2.7. To get a sense magnitude for the standard gain from trade, imports as a share of GDP increased from $14 \%$ to $28 \%$ in the period of our data. Then, the welfare gain in Arkolakis et al. (2012) with an elasticity $\sigma=5$ (between 2 and 10 , and no intermediate inputs) is $(0.72 / 0.86)^{-1 / 5}-1=3.6$ percent. 
in the TFP regressions, but like Table 2, the difference between the smallest and largest quartile is not always statistically significant. The robust finding is the negative coefficient on output tariffs interacted with the smallest quartile of sales for all dependent variables. As previously explained, the model only rationalizes these results if the fixed cost to differentiate is small, a sufficient condition for large and widespread decreases in foreign costs to increase differentiation overall (not just in some sectors relative to others).

\section{Conclusion}

We set out to narrow the gap between the academic literature and the prevailing view among policy makers and economists that tariff cuts are good for the performance of import-competing firms. We develop a stylized extension of Atkeson and Burstein (2008), in which import-competing firms escape foreign competition by specializing in new market niches (nests). Since these product-differentiation strategies to escape import competition improve welfare in the model, they provide a rationale for policy makers' view.

Revenue productivity, the standard measure of firm performance in the empirical literature, is a poor measure of product differentiation because it confounds the positive effects of import competition on innovation with negative pro-competitive effects on markups. We circumvent this difficulty using data on new goods and sectoral skill intensity which are comparable across time even in periods of large changes in demand, technologies and output, such as trade liberalization episodes.

Our proposed mechanism may be relevant in other contexts. Firms innovating to escape competition in established market segments may spur economic growth in a closed economy. Fort et al. (2018) associate import competition in the United States to shifts of manufacturing firms to the service sector, suggesting that strategies to escape competition may accelerate structural change. ${ }^{32}$ Differentiation may also factor in a multinational's decision to serve a foreign market through exports or an affiliate, if the affiliate is better positioned to offer non-tradable services and greater customization.

\section{References}

Acemoglu, D., D. Autor, D. Dorn, G. H. Hanson, and B. Price (2016). Import competition and the great us employment sag of the 2000s. Journal of Labor Economics $34(\mathrm{~S} 1)$, S141-S198.

\footnotetext{
${ }^{32}$ See Cravino and Sotelo (2019) for other effects of trade on structural change.
} 
Ackerberg, D. A., K. Caves, and G. Frazer (2015). Identification properties of recent production function estimators. Econometrica 83(6), 2411-2451.

Aghion, P., N. Bloom, R. Blundell, R. Griffith, and P. Howitt (2005). Competition and innovation: An inverted-u relationship. The Quarterly Journal of Economics 120(2), 701-728.

Aghion, P., J. Cai, M. Dewatripont, L. Du, A. Harrison, and P. Legros (2015). Industrial policy and competition. American Economic Journal: Macroeconomics 7(4), 1-32.

Akcigit, U., S. T. Ates, and G. Impullitti (2018). Innovation and trade policy in a globalized world. Technical report, National Bureau of Economic Research.

Amiti, M., O. Itskhoki, and J. Konings (2014). Importers, exporters, and exchange rate disconnect. American Economic Review 104(7), 1942-78.

Amiti, M. and J. Konings (2007). Trade intermediate and productivity: Liberalization, inputs, from indonesia evidence. The American Economic Review 97(5), 1611-1638.

Arkolakis, C., A. Costinot, D. Donaldson, and A. Rodríguez-Clare (2017). The elusive pro-competitive effects of trade. Review of Economic Studies.

Arkolakis, C., A. Costinot, and A. Rodríguez-Clare (2012). New trade models, same old gains? American Economic Review 102(1), 94-130.

Atkeson, A. and A. Burstein (2008). Pricing-to-market, trade costs, and international relative prices. The American Economic Review 98(5), 1998-2031.

Attanasio, O., P. K. Goldberg, and N. Pavcnik (2004). Trade reforms and wage inequality in colombia. Journal of Development Economics 74(2), 331-366.

Autor, D. H., D. Dorn, and G. H. Hanson (2013). The china syndrome: Local labor market effects of import competition in the united states. 103(6), 2121-2168.

Aw, B. Y., M. J. Roberts, and D. Y. Xu (2011). R\&d investments, exporting, and productivity dynamics. The American Economic Review 101(4), 1312-1344.

Bernard, A. B., J. Eaton, J. B. Jensen, and S. S. Kortum (2003). Plants and productivity in international trade. American Economic Review 93(4), 1268-1290.

Bøler, E. A. (2019). Technology-skill complementarity in a globalized world. CEPR http://ww. .estherboler.com/files/boler_jmp.pdf. 
Bøler, E. A., A. Moxnes, and K. H. Ulltveit-Moe (2015). R\&d, international sourcing and the joint impact on firm performance. The American Economic Review 105(12), 3704-3739.

Boyd, G., N. Abhijeet, C. Richter, and S. Laprise (2008). Asian automakers: Sector outlook. CLSA Report.

Brandt, L. and E. Thun (2010). The fight for the middle: upgrading, competition, and industrial development in china. World Development 38(11), 1555-1574.

Brandt, L. and E. Thun (2016). Constructing a ladder for growth: policy, markets, and industrial upgrading in china. World Development 80, 78-95.

Brandt, L., J. Van Biesebroeck, L. Wang, and Y. Zhang (2017). Wto accession and performance of chinese manufacturing firms. American Economic Review 107(9), 27842820.

Broda, C. and D. E. Weinstein (2006). Globalization and the gains from variety. The Quarterly Journal of Economics 121(2), 541-585.

Buera, F. J. and E. Oberfield (2016). The global diffusion of ideas. Technical report, National Bureau of Economic Research.

Bustos, P. (2011). Trade liberalization, exports and technology upgrading: Evidence on the impact of mercosur on argentinian firms. The American Economic Review 101(1), 304-340.

Caliendo, L. and E. Rossi-Hansberg (2012). The impact of trade on organization and productivity. The Quarterly Journal of Economics 127(3), 1393-1467.

Chen, C. and C. Steinwender (2019). Import competition, heterogeneous preferences of managers, and productivity. NBER Working Paper, No w25539.

Cravino, J. and S. Sotelo (2019). Trade induced structural change and the skill premium. American Economic Journal: Macroeconomics 11(3), 289-326.

De Loecker, J. (2007). Do exports generate higher productivity? evidence from slovenia. Journal of international economics 73(1), 69-98.

De Loecker, J. and F. Warzynski (2012). Markups and firm-level export status. The American Economic Review 102(6), 2437-2471. 
DeLoecker, J., P. K. Goldberg, A. Khandelwal, and N. Pavcnik (2016). Prices, markups and trade reform. Econometrica 84(2), 445-510.

Dhingra, S. and J. Morrow (2018). Monopolistic competition and optimum product diversity under firm heterogeneity. Journal of Political Economy.

Dix-Carneiro, R. and B. K. Kovak (2017). Trade liberalization and regional dynamics. American Economic Review 107(10), 2908-46.

Dixit, A. K. and J. E. Stiglitz (1977). Monopolistic competition and optimum product diversity. The American Economic Review 67(3), 297-308.

Du, L., A. Harrison, and G. H. Jefferson (2012). Testing for horizontal and vertical foreign investment spillovers in china, 1998-2007. Journal of Asian Economics 23(3), 234-243.

Edmond, C., V. Midrigan, and D. Y. Xu (2015). Competition, markups, and the gains from international trade. The American Economic Review 105(10), 3183-3221.

Eslava, M., A. C. Fieler, and D. Y. Xu (2015). (indirect) input linkages. The American Economic Review Papers and Proceedings 105(5), 662-666.

Eslava, M., J. Haltiwanger, A. Kugler, and M. Kugler (2013). Trade and market selection: Evidence from manufacturing plants in colombia. Review of Economic Dynamics 16(1), $135-158$.

Farhoomand, A. and M. Schuetz (2007). Chery automobile company: Evolution of the chinese automotive industry. Asia Case Research Center at the University of Hong Kong HKU676.

Feng, D. and X. Wei (2015). Haier electronics. CLSA Report.

Fernandes, A. M. (2007). Trade policy, trade volumes and plant-level productivity in colombian manufacturing industries. Journal of International Economics 1(71), 52-71.

Fieler, A. C., M. Eslava, and D. Y. Xu (2018). Trade, quality upgrading, and input linkages: Theory and evidence from colombia. The American Economic Review 108(1), $109-46$.

Fort, T. C., J. R. Pierce, and P. K. Schott (2018). New perspectives on the decline of us manufacturing employment. Journal of Economic Perspectives 32(2), 47-72. 
Foster, L., J. Haltiwanger, and C. Syverson (2008). Reallocation, firm turnover, and efficiency: Selection on productivity or profitability? American Economic Review 98(1), 394-425.

Goldberg, P. K., A. K. Khandelwal, N. Pavcnik, and P. Topalova (2009). Trade liberalization and new imported inputs. The American Economic Review, Papers and Proceedings 99(2), 494-500.

Goldberg, P. K., A. K. Khandelwal, N. Pavcnik, and P. Topalova (2010). Imported intermediate inputs and domestic product growth: Evidence from india. The Quarterly Journal of Economics 125(4), 1727-1767.

Goldberg, P. K. and N. Pavcnik (2004). Trade, inequality, and poverty: What do we know? evidence from recent trade liberalization episodes in developing countries. Brookings Trade Forum, 223-269.

Goldberg, P. K. and N. Pavcnik (2007). Distributional effects of globalization in developing countries. Journal of Economic Literature 45(1), 39-82.

Gorodnichenko, Y., J. Svejnar, and K. Terrell (2010). Globalization and innovation in emerging markets. American Economic Journal. Macroeconomics 2(2), 194.

Harrigan, J., A. Reshef, and F. Toubal (2019). Techies, trade, and skill-biased productivity. Paris School of Economics http://www.parisschoolofeconomics.com/ reshef-ariell/papers/HRT_productivity_nov18.pdf.

Harrison, A. E. (1994). Productivity, imperfect competition and trade reform: Theory and evidence. Journal of international Economics 36(1-2), 53-73.

Holmes, T. J. and J. A. Schmitz (2010). Competition and productivity: A review of evidence. Annual Review of Economics 2(1), 619-642.

Holmes, T. J. and J. J. Stevens (2014). An alternative theory of the plant size distribution, with geography and intra-and international trade. Journal of Political Economy 122(2), $369-421$.

Javorcik, B. S. (2004). Does foreign direct investment increase the productivity of domestic firms? in search of spillovers through backward linkages. The American Economic Review 94(3), 605-627.

Kugler, M. and E. Verhoogen (2011). Prices, plants and product quality. Review of Economic Studies 79(1), 307-339. 
Lileeva, A. and D. Trefler (2010). Improved access to foreign markets raises plant-level productivity...for some plants. The Quarterly Journal of Economics 125 (3), 1051-1099.

Lim, K., D. Trefler, and Y. Miaojie (2019). Trade and innovation: The role of scale and competition effects. University of Toronto, mimeo.

Linarello, A. (2018). Direct and indirect effects of trade liberalization: Evidence from chile. Journal of Development Economics 134, 160-175.

Melitz, M. J. (2003). The impact of trade on intra-industry reallocations and aggregate industry productivity. Econometrica 71 (6), 1695-1725.

Melitz, M. J. and G. I. Ottaviano (2008). Market size, trade, and productivity. The review of economic studies 75(1), 295-316.

Nocke, V. (2006). A gap for me: Entrepreneurs and entry. Journal of the European Economic Association 4(5), 929-956.

Olley, G. S. and A. Pakes (1996). The dynamics of productivity in the telecommunications equipment industry. Econometrica 64(6), 1263-1297.

Perla, J., C. Tonetti, and M. E. Waugh (2015). Equilibrium technology diffusion, trade, and growth. Technical report, National Bureau of Economic Research.

Pierce, J. R. and P. K. Schott (2016). The surprisingly swift decline of us manufacturing employment. American Economic Review 106(7), 1632-62.

Porter, M. E. (2008). Competitive strategy: Techniques for analyzing industries and competitors. Simon and Schuster.

Rose, G. (2015). Special entrepreneurship issue: Here come the disruptors. Foreign Affairs $94(1)$.

Sampson, T. (2015). Dynamic selection: an idea flows theory of entry, trade, and growth. The Quarterly Journal of Economics 131(1), 315-380.

Shu, P. and C. Steinwender (2019). The impact of trade liberalization on firm productivity and innovation. Innovation Policy and the Economy 19(1), 39-68.

Spence, M. (1976a). Product differentiation and welfare. The American Economic Review $66(2), 407-414$. 
Spence, M. (1976b). Product selection, fixed costs, and monopolistic competition. The Review of economic studies 43(2), 217-235.

Teagarden, M. B. and C. Fifi (2015). Xiaomi, inc.: The rise of a chinese indigenous competitor. Thunderbird School of Global Management TB0417.

Topalova, P. (2010). Factor immobility and regional impacts of trade liberalization: Evidence on poverty from india. American Economic Journal: Applied Economics 2(4), $1-41$.

Tybout, J. R. (2003). Plant- and firm-level evidence on the 'new' trade theories. In E. K. Choi and J. Harrigan (Eds.), Handbook of International Trade. Blackwell Publishing Ltd.

Wooldridge, J. M. (2010). Econometric analysis of cross section and panel data. MIT press. 